\title{
Dams as Symbols of Modernization: The Urbanization of Nature Between Geographical Imagination and Materiality
}

\author{
Maria Kaika \\ School of Geography, Oxford University
}

\begin{abstract}
The article offers an analysis of the iconography and symbolism of dam constructions at three levels: first, as embodiments of the dialectics between geographical imaginations and material practices in the process of modernization; second, as symbols of modernity's quest to conquer and urbanize nature; and third, as the catalysts for reconfiguring the relationship between nature and the city. The article grounds its analysis on the study of the Marathon dam, the first dam project for watering Athens, constructed in the 1920s. Being the biggest dam construction at the time in the Balkans, it became an iconic marker of Athens's modernization and of Greece's modernist project for controlling and taming nature. It also signaled a new era of trade relations between the United States and Greece by introducing American capital and work practices into Greece. However, this decidedly modern project was wrought with heavy neoclassical ornamentation and symbolism, and was veneered with the same marble as that used for the Parthenon. The article interprets this as an effort to reconcile iconographically the two prevailing geographical imaginations that infused the modernizing desires of Athens: modernizing the city through connecting it to the West and modernizing it through reconnecting it to its classical past. In the analysis, the article draws on original material from the archives of the National Library of Greece in Athens. Key Words: Athens, dams, Marathon, urbanization, water.
\end{abstract}

Life has few pleasures to compare with dam-building. ... The pleasure comes from the elegance of the compromise you strike between where the water wants to go (guided by gravity and the medium it's moving over), and what you want to do with it.

-Banks (1984)

1

he modernist quest to tame, control, and discipline nature has been described by many scholars as "Modernity's Promethean Project" (Proudhon 1972; Marx 1992; Foster 2000). Prometheus, meaning "the one who foresees," stole fire from the gods and brought it to human beings, turning them "from savages to men" (Aeschylus 1975, ca. 430 BC). For this reason, Prometheus was recognized in the ancient Greek world as the father of all arts and sciences. More than twenty centuries later, the Enlightenment found in the same mythological figure the cultural icon of the Modern Hero. ${ }^{1}$ It was the Scientist and the Engineer who would become the modern Prometheus, the One Man who would stand alone against Nature (Glacken 1967; Berman 1983; Bewell 1989; Latour 1993). From Scott's tragic expedition to the South Pole (Katz and Kirby 1991) to Teller's "scientific horror" scenarios to construct harbors using the power of nuclear explosions (Kirsch and Mitchell 1998), the heroes of modernity promised to dominate nature and deliver human emancipation employing imagination, creativity, ingenuity, romantic heroic attitude, and a touch of hubris against the given order of the world.

This same Modernist quest to tame and control nature also became central to the production, metabolism, and expansion of modern cities. From the great urban sanitation projects of the nineteenth century (Gandy 1999; Halliday 1999; Harvey 2003) to the mid-twentiethcentury "wholesale transformation of natural environments" (Cosgrove 1990, 8) that produced electricity and water to feed urban growth, the production of modern cities went hand in glove with the production of nature (Smith 1984; Castree and Brown 1998). These two processes are so indistinguishable from each other that many scholars conceptualize them as part of one single process: "the urbanization of nature" (Cronon 1991; Harvey 1996; McCully 1996; Swyngedouw 1997, 2004; Fischer and Hajer 1999; Swyngedouw and Kaika 2000; Graham and Marvin 2001; Robbins, Polderman, and Birkenholtz 2001; Gandy 2002; Wolch, Pincetl, and Pulido 2002; Desfor and Keil 2004).

The dialectics between the production of nature and the production of cities is paradigmatically manifested in dam projects: transmuting "natural" landscapes in their making, while making the production and expansion of 
urban landscapes possible, these technological shrines exemplify the messy dialectics between creation and destruction inherent in Modernity's Promethean Project. However, despite the catalytic impact that dam projects have had on the formation of modern urban landscapes, these projects have received very little attention in the emerging field of geographical enquiry on the urbanization of nature. So far, the study of dams has been confined to the fields of political ecology (Cummings 1990; Heming, Waley, and Rees 2001), politics and planning (Brismar 2002; Doering 2003), and straightforward history (Allen 1952; Worster 1985; Dunar and McBride 2001). The study of the iconography of dams has equally fallen outside the interest of the field of enquiry on the iconography of landscapes and monuments. Over the past two decades, this body of literature has given us excellent analyses of monumental histories and iconographic landscapes (Cosgrove and Petts 1990; Matless 1992; Daniels 1993; Atkinson and Cosgrove 1998), but dams have remained largely outside the interests of this field of analysis, despite the fact that these striking modern constructions served as iconic landmarks of modernization.

Bringing together the body of academic inquiry that examines the urbanization of nature as a socioenvironmental and inherently political process on the one hand, and the literature that examines monumental history on the other, this article offers (1) an analysis of dam projects as embodiments of the dialectics between geographical imaginations and material practices in the process of modernization; (2) an inquiry into the power struggles involved in the implementation of dam projects as part of modernity's quest to conquer and urbanize nature; and (3) a discursive and iconographic analysis of dam projects as symbols of modernization and as catalysts for reconfiguring the relationship between nature and the city. The article demonstrates how the "heroic" act of dam building has been as much the product of socially and culturally embedded plans, dreams, and geographical imaginations of modernization (Gregory 1994), as it has been the product of the historical and geographical conditions under which these plans and dreams were pursued (Frenkel 1996). Although the impetus to pursue these decidedly modern projects has been part of the geographical imagination for producing sanitized urban environments, their material production has been contingent on technology and scientific expertise, human labor, capital investment, and social and political power. This article presents the construction of dams as instances of modernization in which imagination and materiality fused in a singular process of creative destruction that changed "natural" and urban landscapes irrevocably.
The article grounds its inquiry on an analysis of the production of the Marathon dam, the first dam project for watering Athens, which was implemented in the 1920s. Modern Greece lies more or less outside the cognitive map of Anglo-American geographers and arguably outside the interests of the global knowledge economy (Kitchin 2005). A search in the Annals of the Association of American Geographers for the period 19112005 returns only two articles on modern Greece (Constantinou and Diamantides 1985; Loukaki 1997) and two book reviews. Therefore, the present article's inquiry into the social political and economic conditions that led to the production of the Marathon dam not only offers an analysis of an important instance in the urbanization of nature and the production of modern cities, but also exemplifies "the 'singular diversity' of geography ... beyond Anglo-America" (Kitchin 2005, 9).

The first part of the article canvasses the two geographical imaginations and wish-images for a modern Athens that prevailed after the city became the capital of the modern Greek state in 1834: one identified modernizing Athens with connecting it to the West and to an industrial future; the other depicted modernization as reconnecting the city to its ancient past. The coexistence of these two imaginations is interpreted as two sides of the same coin, as the Janus-faced desire of Greece to drag the cognitive boundaries of the West toward its own position on the map (Gregory 1994, 1995).

The second part of the article examines the central role that the urbanization of water played in the process of modernizing and westernizing Athens, and documents the tortuous, and ultimately failed, early attempts (1834-1922) to water the city. At a time when western cities were buzzing with sanitation projects, Athens could not enter the constellation of European metropolises without adequate water running through its veins. However, the ambitious desire to implement large-scale water supply infrastructure projects was constantly frustrated by the humble materiality of a country in debt, unable to embark on its own modernizing trajectory. Although the Greek state was successful in securing external loans for the development of railway and telecommunications infrastructure, it was not equally successful in raising funds for urban water supply projects, despite their social and political importance. Lack of funding, combined with the West's fascination with bringing Greece's classical past back to light, resulted in subverting the process of watering and sanitizing the city into an archaeological project. This "archaeological modernization" is exemplified by the efforts to excavate and restore the city's ancient aqueduct (Hadrian's 
aqueduct) as a means of improving water supply and sanitation while simultaneously reconnecting the city to its ancient veins.

The third part of the article offers an interpretation of the lack of interest of western capital in investing in water supply projects in Greece during the nineteenth century. Although a sovereign state, Greece's economic dependency on advanced western economies submitted it to a position similar to that of the colonies within the international division of labor. This dependency dictated a modernizing process that resembled very closely what Headrick $(1981,1988)$ terms "selective modernization," a typical nineteenth-century colonial development practice that favored transportation and telecommunication projects over water supply and irrigation projects, as the latter were expected to yield neither money nor symbolic capital for colonial regimes.

The fourth part of the article examines the domestic and geopolitical changes that finally enabled Greece to shift to a modernizing "engineering paradigm" and culminated in the construction of the Marathon dam in the 1920s. Ulen \& Co, an American construction giant, undertook the dam construction works and the subsequent management of the water supply system of Athens. The contract between the Greek state and Ulen \& Co introduced American capital and American work practices to Greece for the first time. The article relates the financing of the Marathon dam project by American capital (in the form of a state loan) to geopolitical changes in the Balkan area and the "Near East" after the end of World War I.

The fifth part of the article is a discursive and iconographic analysis of the Marathon dam. Although a decidedly modern project, the dam was nevertheless emblematically located on the site of the ancient battlefield of Marathon, was draped with classical ornamentation and symbolism, and was veneered with the same type of marble as that used for the construction of the Parthenon. The Marathon dam became a symbol of the Greek state's successful pursuit of modernization, but it also contributed to reconciling iconographically the dual geographical imagination for modernizing Athens. The geographical imagination of a city reconnected to its past became incorporated in the material production of its future.

Finally, by juxtaposing the Marathon dam to similar constructions in the Western world, the article offers a discursive and iconographic analysis of dam projects as the "collective sublime" of modernity (Marcus 1988; Buck-Morss 1995), and as catalysts for a reconfiguration of the relationship between nature and the city. Often lying outside the cognitive map of urban dwellers, yet central to the function and metabolism of urban life, dams concretize the interdependence between the production of nature and the production of modern cities. On the one hand, dams are central to "freeing" the city from the constraints on its form and function posed by nature (Guillerme 1994). On the other hand, they make the city's metabolism dependent on the perpetual continuation of a Modernist Promethean Project to conquer nature.

The original research for this article is based on archival material from the Newspaper and Magazine Archives at the National Library of Greece. A systematic search of the archival material covered the period 18931969. Since the archives offer different year coverage for different publications, the following publications were researched between the years thus indicated: E $\mu \pi \rho$ ós

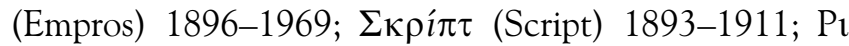

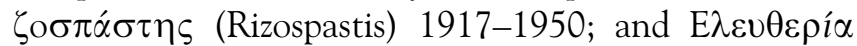
(Eleutheria) 1944-1955. I also examined material published by the Water Supply and Sewerage Corporation of Athens (EY $\triangle \mathrm{A} \Pi)$ and by Ulen \& Co, as well as older secondary material, including chronicles of the city's water supply development (Paraskevopoulos 1907; Genidounias, Koumousis, and Loprestis 1923; Gerontas and Skouzes 1963; Kalantzopoulos 1964; Kordellas 1979; Koumparelis 1989). This older secondary material was examined alongside the original archival material, permitting the recasting of the "watering of Athens" within a new interpretative framework.

\section{A Double Vision of Modernization: Between Geographical Imagination and Materiality}

After the Greek War of Independence against the Ottoman Empire (1821-1830), the main aspiration of the young Greek state was to shake off its Ottoman past and enter the constellation of modern (western) European states. Athens was chosen as the capital of the young state mainly in anticipation of "the benefits that Greece would reap if the famous city regenerated itself as its capital" (Mpiris 1996, 21). A speech given on 25 September 1834 by Kleomenis, the President of the Committee for the Restoration of Athens, indicated that the aspirations for the future of the city were very high: "A marvelous voice, a voice reassuring the world of a great future is echoing today ... Athens! The ancient metropolis of the world, the temple of admiration of centuries is being erected; the glorious Athens!!! Prepare! Prepare the way of the Lord!"2 (cited in Mpiris 1996, 40-41). 
However, these ambitious aspirations met the humble materiality of post-independence Greece, a country ravaged by warfare, already in debt, sparsely populated (seventeen inhabitants per $\mathrm{km}^{2}$ in 1839), and with an economy based predominantly on agriculture (Agriantoni 1986). Athens itself was a capital in ruins, a tabula rasa, its boundaries demarcated only by entry/exit points and remnants of transport routes (Karydis 1988). Most of the city's buildings had been destroyed during the long war, and most of its population had fled (Wordsworth 1837; Marcellus 1839). In 1830, M. Michaud painted a bleak image of Athens from the vantage point of a westerner (a Frenchman) who was visiting "the Orient": "We are walking within piles of scattered ruins, pathways in the middle of wrecks, we jump over piles of stones, relics of old walls, pillars stretched over the dust.... There is not a single street left, not a single public square, garden, chapel, or church" (Michaud and Poujoulat 1830,32$)$. In contrast to other nineteenth-century western metropolises that were busily constructing infrastructure and sanitation systems, the showcase of the young Greek state possessed no assets other than its glorious past. There was not even a clear hegemonic project for modernizing Athens since there was no single social group that could persevere in leading the country's modernization. The nascent merchants and bourgeoisie had fled the restrictive sociopolitical and economic structures of Ottoman rule in search of more liberal territories in which to pursue their economic activities (Tsoukalas 1977; Milios 2000). These groups formed a strong diaspora bourgeoisie that thrived abroad in places like Trieste, Odessa, and Alexandria, but they were reluctant to transfer their economic operations back to Greece even after independence was achieved (Moskoph 1974; Tsoukalas 1981).

Indeed, the very existence of a distinct native Greek bourgeoisie that could champion Greece's industrial development is still a matter of dispute among scholars (Moskoph 1974; Tsoukalas 1977, 1981; Milios 2000). According to Tsoukalas (1981), the development and crystallization of a domestic Greek bourgeoisie never actually occurred. Nevertheless, there were a series of actors who competed over political, social, and economic power within the newly formed Athenian territory. Among them were, first, the diaspora bourgeoisie who, though not interested in direct investment in Greece, were nevertheless keen to muster political power and assume the role of the "great national benefactors"; second, Christian landed privileged classes and Christian merchant farmers, who, together with local administrators, had amassed significant social and political power during the last period of Ottoman rule; third, the royal family, a new institution modeled after the West, and led by King Otto and Queen Amalia, both imported from Bavaria; and finally, the newly established state apparatus, with its emerging strata of political elites and state bureaucrats. These actors pursued different economic interests and promoted different political and social agendas, which reflected disparate interpretations of what modernizing Athens should actually mean at an ideological/discursive level, and what it should entail at a practical/material level.

Without a clearly formed domestic bourgeoisie claiming its space and pioneering a distinctly modernizing program, the modernization of the Athenian urban landscape remained up for grabs and open to interpretation for the best part of the nineteenth century. For the diaspora bourgeoisie, modernizing Athens meant commissioning the best foreign architects to design impressive public buildings that would carry the benefactors' names inscribed on their façades (Moskoph 1974; Mpiris 1996). For Queen Amalia, modernizing Athens meant filling the city with exotic varieties of trees, following the model of the great metropolises of her native country (Kalantzopoulos 1964; Kaika 2005). For agricultural workers, modernization emblematized the struggles for land reform and land rights (Vergopoulos 1975; Tsoukalas 1981). For the peasantsturned-manual-workers, who were slowly moving into Athens from the countryside, modernization was identified with striving for better salaries and living standards (Agriantoni 1986). For the landed elites, modernizing involved clinging on to the political and economic power that they had accrued under Ottoman rule (Vergopoulos 1975; Tsoukalas 1981). Finally, for the central state, modernization entailed dismantling the Ottoman social and institutional structures and promoting the formation of a domestic bourgeoisie that would pioneer industrial development (Moskoph 1974; Milios 2000).

These often opposing agendas and conflicting interests culminated in two geographical imaginations/visions as to how best to modernize Athens. The first vision saw modernization as connecting the city to the West, embracing progress and industrialization and pursuing big engineering projects that would sanitize and beautify the city. The second vision saw modernization as reconnecting the city to its ancient (classical) past by forging links between modern and classical Athens, while leapfrogging over the Ottoman "interval," at representational, discursive, and material levels.

The first vision, of modernization as westernization, is neither surprising nor exclusively Greek, since modernization is a quintessentially western enterprise. The second vision, in which Greece's classical past was to be marshaled, would be easy to dismiss as a form of nationalistic illusion. However, establishing a link between 
western modernization and classical Greece was neither a Greek invention nor an entirely Greek enterprise. It was an integral part of the broader European tradition of modernization and part of the Enlightenment's quest for constructing a common identity of and for "the West." Ironically, while Greece was still under Ottoman rule and thus part itself of "the Orient," its classical past provided the foundation on which the Enlightenment constructed a common identity for "the Western world," against which "the Orient" was juxtaposed (Gregory 1995; Said 1995), as well as a common vision for western democracy. The Enlightenment ideal of a particular type of freedom that could flourish only within western democracies drew inspiration from the intellectual legacy of fifth-century BC Greek philosophy. The Athenian classical past was reinvented by the Enlightenment as the cradle of western civilization, and this reinvention in turn provided the backdrop for the aesthetic infatuation of western aristocracy and bourgeoisie with classical Greek style (Middleton and Watkin 1987; Hersey 1988; Etlin 1994). Between 1818 and 1850 the Greek Revival style grew to be so popular in the United States that it became known as the "National Style." European cities were equally infatuated: Edinburgh, adopted the style to such an extent that it became known as the "Athens of the North" (Clarke 2001).

In the late eighteenth and early nineteenth centuries, the Greek Revival gave way to neoclassicism, a style that also sought to recapture the spirit of ancient Greece and Rome, and became dominant in European art and architecture (Chilvers 1996; Clarke 2001). Both neoclassicism and the Greek Revival were adopted by Europeans and North Americans as the "noblest" styles for private bourgeois homes, but they also conveniently filled the void created by the need to build nonreligious monumental public buildings in a secularized western society, including: the United States Capitol in Washington D.C. (1773-1830; dome 1851-1863), the Statue of Liberty and Observation Tower (1884-1886), the Custom House in New York (1833-1842), the British Museum in London (1823-1847), the Ashmolean Museum in Oxford (1839-1842), St George's Hall in Liverpool (1838-1854), la Bibliothèque Nationale in Paris (1862-1868), and la Galleria Vittorio Emanuele in Milan (designed 1861, built 1865-1877).

As part of the same fascination of the Western world with classical Greece, liberating contemporary Greece from Ottoman rule and from "the Orient" and enabling her to (re)join the Western world also became a col-

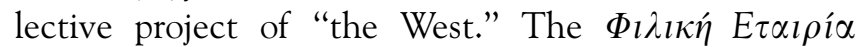
(Philhellenic Society, formed in 1814 in Odessa) counted numerous friends among the West European bourgeoisie and intelligentsia, and was instrumental in sparking and funding the Greek War of Independence. To this end, Britain provided an initial "Independence loan" of $£ 800,000$ in 1824 , followed a year later by an additional $£ 2$ million (Psiroukis 1974). Once the War of Independence was over, the newly established Greek state tried to construct its own identity by disconnecting from its Ottoman past, in an attempt to conform to the image of and for Greece that the West had already formulated. The celebration of the country as the cradle of western civilization had profound effects on the way emerging Greek elites perceived their country's place in the Western world. It is precisely within this context that the vision to reconnect Athens to its classical past ought to be understood. Eager to connect to a western capitalist future, yet unable to "take off" on its own accord, Greece used its buried classical past as a more direct means of "westernizing" (Godlewska 1995; Gregory 1995; Peckham 2001). In this way, Athens became something of a nineteenth-century Cinderella, longing to be transformed by the hand of progress in order to be finally embraced by her western prince. First, however, she had to pay her dues to her past. The patronizing attitude that demanded Greece's transformation into something that would fit the western imagery is exemplified by the German archaeologist L. Ross, who visited Athens in 1832:

Your gaze falls upon the city ... and you wander about in sorrow, the way you do when you encounter a beloved old girlfriend whom you have left in blooming beauty and who is now welcoming you with deformed face and plucked hair. This is not the glorious Athens. ... Had it not been for the temple of Theseus, and for the ruins of the Acropolis, one would find it hard to believe that one is indeed in Athens.

—(Cited in Gerontas and Skouzes 1963, 48)

It was only by reconnecting to her essentialized classical/western identity that Athens could claim its rightful place among the great metropolises of the Western world. Seen within this context, the two visions for modernizing Athens figure as the two sides of the same coin, together constituting the Janus-faced efforts to drag Greece within the cognitive geographical boundaries of the West.

\section{The Role of Water in Producing a Modern City. "The Best Politician Amongst You Shall Be the One Who Will Bring Water into Athens"}

The urbanization of water played a central role in materializing both visions for modernizing Athens. In the 
process of transformation into a western metropolis, one of the city's most urgent tasks was sanitation. Without an adequate water supply Athens could not even start to imagine, let alone materialize, becoming part of the constellation of western metropolises. The nineteenth century was the time when urban sanitation and infrastructure projects became a matter of prestige and national pride across the Western world. In London, eliminating the "great stink" from the heart of the Imperial capital became a national project of the first order (Halliday 1999). This project was pursued through institutional changes and large-scale engineering works, which included the construction of the London sewers and the embankment of the Thames (Oliver 2000). In Paris, sanitizing the expanding city became one of Baron Haussmann's main preoccupations during his service as Prefect of the Seine (1853-70; Gandy 1999; Harvey 2003). Bringing adequate fresh water into Athens became an equally urgent political and social issue that was central to producing a "hygienic" city (Gandy 2004). The importance of water was affirmed by the French politician Clemenceau, who asserted, when he visited Athens in 1899, that: "The best politician amongst you shall be the one who will bring water into Athens" (cited in Gerontas and Skouzes 1963, 111).

Channeling water into the growing city was not to be an easy task, however. It required major capital investment, adequate supply of labor, new technology, social consensus, political stability, and commitment-but most of these factors were absent. With no industrialization prospects in sight, no colonies from which to extract wealth, and carrying the debt from its Independence loans, Greece could not finance the muchdesired sanitation projects. For Athenians, acquiring water remained a daunting task, and Athenian women either collected it on a daily basis from public wells and springs or bought it from water vendors at high prices (Gerontas and Skouzes 1963).

Lack of funding, combined with the fascination with bringing Athens's classical past to light, subverted the process of watering and sanitizing the city into an archaeological project. This archaeological modernization is exemplified in the efforts to excavate and restore Hadrian's aqueduct. The aqueduct was a feat of ancient engineering technology that had been commissioned during the Greco-Roman period, under the command of the Roman emperor Hadrian, and had been completed in AD 140 by Hadrian's successor, Antonius Pius. The aqueduct channel $(0.7-0.8 \mathrm{~m} \times 1.2-1.6 \mathrm{~m})$ was constructed in vaulted brick, and ran for a length of $25 \mathrm{~km}$, carrying water from the foothills of Mt. Parnitha, next to Tatoi (see Figures 1 and 2), to a water storage reservoir

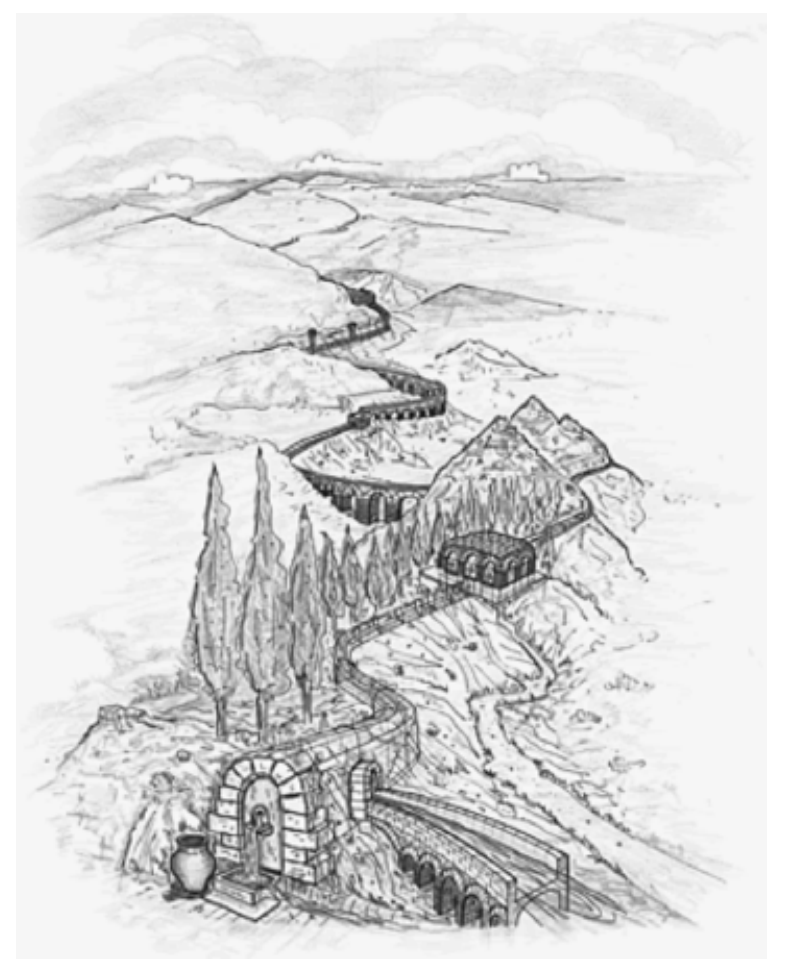

Figure 1. Impression of the original course of Hadrian's aqueduct through the mountains of Parnitha and into the center of Athens. (Copyright: Water Supply and Sewerage Corporation of Athens. Source: "The water supply of Athens: Past and present", Water Supply and Sewerage Corporation of Athens. Available at http:// www.eydap.gr/media/Stagonoulis/stagonoulispopup/index_gr.htm [last accessed 2 October 2005])

on Mt. Lycabettus, now at the heart of the contemporary city. The depth of the channel varied from 2.5 to $40 \mathrm{~m}$ (Gerontas and Skouzes 1963; Crouch 1993). This ancient water supply system remained operational until the fifteenth century, when the Ottomans decided to abandon it in favor of developing a system of public fountains for the city. After the founding of the Modern Greek State, Hadrian's aqueduct was in a poor state of repair. However, the local authorities trusted that, if restored, the aqueduct would provide both a relatively inexpensive solution to Athens's water supply problem and an indisputable material symbol of the city's reconnection to its celebrated ancient veins. The restoration of the aqueduct soon became something of an obsession for the municipal authorities, an urban fetish, whose myth was stubbornly pursued throughout the nineteenth century. From 1834 to 1889 the lion's share of funding for water supply projects was channeled into excavating, reconstructing, and reconnecting the ancient aqueduct to modern Athens (see Table 1).

The Hadrian aqueduct restoration mission coincided with a period of Western European fascination with 


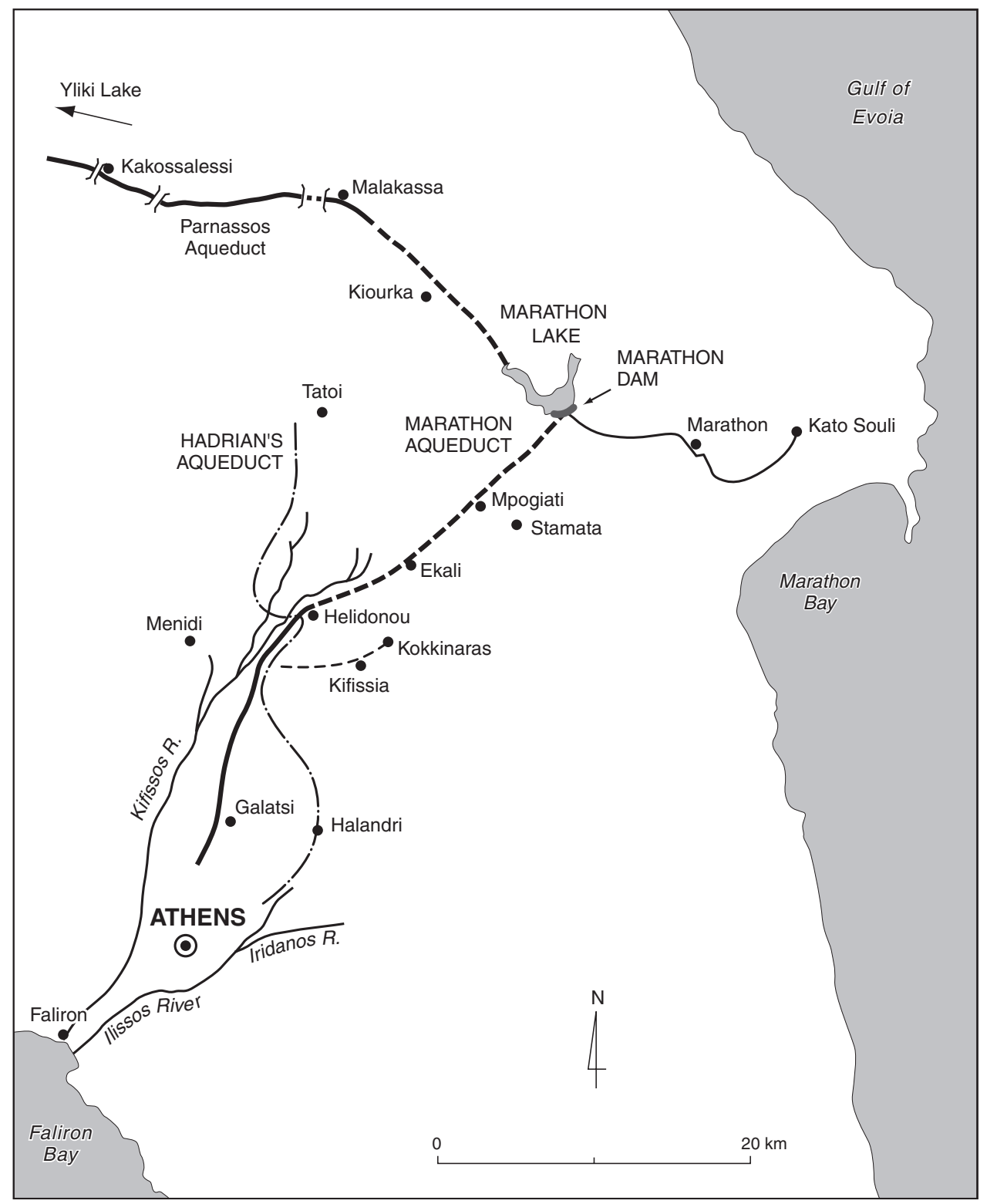

Figure 2. Hadrian's aqueduct and the Marathon dam. The map indicates the course of Hadrian's aqueduct $(-\bullet-)$, the course of the Marathon aqueduct (-- ), and the location of the Marathon dam and reservoir. (Source: Compiled by the author based on a background map from Koumparelis 1989, 60)

classical archaeology. Williams (1990) argues that the thriving "humanistic" archaeology of the nineteenth century was aimed at, among other things, "gratifying the self-esteem of the Westerner." Greece's recent independence provided fertile ground for the pursuit of this project. While Hadrian's aqueduct was being excavated, a number of archaeological institutes established branches in Athens-among them the British School at Athens (1886), the German Archaeological Institute (1875), and the American School of Classical Studies (1881) — and subsequently competed against each other in excavating the origins of western civilization (Loukaki 1997). The restoration works at Hadrian's aqueduct succeeded in bringing a total of 3,021 L of water per day into the city (1879). In fact, parts of the ancient aque- duct are still functional today, and are incorporated into the city's contemporary water supply system, thereby making Athens's water both "archaeologized" and "urbanized." 3

Contrary to overly optimistic expectations, however, the restoration of the aqueduct proved not only difficult and more expensive than anticipated, but also inadequate to water Athens. The city's rapid population growth during the late nineteenth century resulted in a dramatic fall in per capita water availability. As Table 2 shows, Athens had $44 \mathrm{~L}$ of water per capita per day available in 1879 with a population of 68,677 , but by 1898 , with a population of 114,000 this had fallen to $16.5 \mathrm{~L}$ (see also Table 3, later, for availability patterns). Thus, although the symbolic value of the restoration works remained 
Table 1. Half a century of restoring Hadrian's aqueduct

\begin{tabular}{|c|c|c|c|}
\hline Date & Amount (drachmas) & Funding source & Works \\
\hline 1833 & 5,000 & State funding & Repair works \\
\hline 1846 & 50,000 & Interest-free state loan & Cleaning and repair works (from Ampelokipi to Psyhiko) \\
\hline 1851-1854 & Data not available & Municipal funding & Replacement of old clay pipes with iron ones \\
\hline 1856 & 20,000 & Interest-free state loan & $\begin{array}{l}\text { Channeling water from the Ampelokipi Reservoir into } \\
\text { the Royal Palace purification plant at Aiolou Street }\end{array}$ \\
\hline 1860 & 150,000 & Application for state loan & Loan refused \\
\hline 1860 & 300,000 & Application for loan from the Bank of Greece & Loan refused \\
\hline 1874-1878 & 727,000 & Loan from the Bank of Greece & Leveling works (from Kolonaki to Ampelokipi) \\
\hline 1879-1887 & Data not available & Loan from the Bank of Greece & Expansion of supply network \\
\hline 1887 & $110,000390,000$ & $\begin{array}{l}\text { State loan and loan from the } \\
\text { Bank of Greece }\end{array}$ & Repair and drilling works \\
\hline 1889 & & \multicolumn{2}{|c|}{ Municipal decision to suspend all repair works on Hadrian's aqueduct } \\
\hline
\end{tabular}

Sources: Compiled by the author based on archival and secondary materials.

undisputable, the use value of pursuing this restoration as the main means of watering and sanitizing the city was put under scrutiny. By the end of the 1890s, even the most fervent defenders of the restoration project realized that the reconnection of Athens to its ancient veins alone would not be sufficient to produce a modern city (Script 1904b). With a population of 200,000 and growing, Athens was marching into the twentieth century without an adequate supply of potable water.

\section{Selective Modernization: On Being Both Modern and Underdeveloped}

\section{The Trouble with Water: Lack of Interest in Financing Water Supply Projects}

After the 1870s, modernizing Athens by means of introducing Western technology and infrastructure increasingly gained momentum over modernizing the city by means of reconnecting it to its past. However, as

Table 2. Water supply of Athens between 1879 and 1931 (after 1910 the figures correspond to the metropolitan areas of both Athens and Piraeus)

\begin{tabular}{lccc}
\hline Year & $\begin{array}{c}\text { Water } \\
\text { supply } \\
\left(\mathrm{m}^{3} / \mathrm{yr}\right)\end{array}$ & $\begin{array}{c}\text { Water supply } \\
\left(\mathrm{m}^{3} / \text { day }-\right. \\
\text { average })\end{array}$ & $\begin{array}{c}\text { Water supply } \\
\text { (L/capita/day }- \\
\text { average })\end{array}$ \\
\hline 1879 & $1,102,665$ & 3,021 & 44 \\
1888 & 876,000 & 2,400 & 18 \\
1898 & 693,500 & 1,900 & 16.5 \\
1923 & $2,920,000$ & 8,000 & 10 \\
1928 & $5,502,617$ & 12,829 & 18 \\
1929 & $8,204,308$ & 22,477 & 30 \\
\hline
\end{tabular}

Sources: Compiled from Michalopoulos (1932), Kalantzopoulos (1964), and Koumparelis $(1989,75)$.
Headrick's superb analysis shows, technology rarely ever flows "on its own accord from 'advanced' to 'backward' areas" (Headrick 1988, 9; see also Headrick 1981, 2000). Greece was no exception; the paradigm shift from archaeological to large-scale engineering projects could not have happened without a transformation of the political-economic configuration that enabled foreign capital to flow into Greece. Two main processes facilitated this (predominantly French and British) investment. The first was related to the wave of liberalism that swept through Europe during the late nineteenth century and also affected the Greek political scene. Charilaos Trikoupis, a reformist liberal who was determined to modernize the country (Clogg 1984), was elected Prime Minister (1882-1885, 1887-1890, and 1892-1895). Through a series of strict economic measures, which included raising indirect taxes and custom duties and exploiting state monopolies, Trikoupis succeeded in regularizing the country's debt. This permitted Greece to secure development loans.

Table 3. Patterns of availability of domestic water supply for Athens

\begin{tabular}{lccccc}
\hline & & \multicolumn{3}{c}{$\begin{array}{c}\text { Patterns of availability } \\
\text { of running water to connected } \\
\text { households (as percentage of } \\
\text { connected households) }\end{array}$} \\
\cline { 3 - 6 } & $\begin{array}{c}\text { No. of } \\
\text { households } \\
\text { connected }\end{array}$ & $\begin{array}{c}\text { Every } \\
\text { 4 days }\end{array}$ & $\begin{array}{c}\text { Every } \\
\text { 3 days }\end{array}$ & $\begin{array}{c}\text { Every } \\
\text { 2 days }\end{array}$ & Daily \\
\hline 1926 (June) & 17,073 & 97 & 1.5 & 1.5 & 0 \\
1927 & 18,128 & 88 & 10.5 & 1.5 & 0 \\
1930 & 23,612 & 3 & 77 & 20 & 0 \\
1931 & 48,043 & 0 & 0 & 15 & 85 \\
1932 & 68,282 & 0 & 0 & 0 & 100 \\
\hline
\end{tabular}

Sources: Koumparelis (1989); Ethnos (1956). 
However, Trikoupis's efforts would not have been as effective had they not coincided historically with a second, arguably more important, process: the recession of western economies. Slackening demand for investment and falling domestic interest rates in Western Europe turned investing abroad into an attractive option, and Greece became a fertile site for western capital in search of a spatial fix (Harvey 1985). The combined favorable domestic and international configuration enabled Greece to raise six external loans of a total nominal value of 630 million drachmas by 1890 (Clogg 1984). Most of these loans were used to promote infrastructure development through contracts with foreign construction companies.

However, the transfer of technology and expertise from the West into Greece was a highly eclectic process (Vaxevanoglou 1996). Although 92 percent of railway infrastructure and 100 percent of the country's telecommunications projects were financed through foreign capital between 1880 and 1925 (Tsotsoros 1995), there was not a single large-scale water supply project that attracted financial support during this period. Between 1883 and 1893 the length of the country's railway track grew from 7 to 568 miles and that period went down in Greek history as "the railway decade." Similarly, the steamship tonnage increased from 8,241 tons in 1875 to 144,975 tons in 1895 (Clogg 1984, 91). But despite the rapid population growth and the accentuation of Athens's water supply and sanitation problems, watering the capital remained confined to excavating and restoring Hadrian's aqueduct.

The lack of interest of foreign capital to fund water supply projects can be attributed to the particular character of Greece's economic development, which has been characterized by many scholars as "colonial" (Koronis 1944, 22; Psiroukis 1964; Leontidou 1989). Although a sovereign state and not a colony, Greece nevertheless bore an economic dependence on advanced western economies similar to that of colonial regimes. This dependence dictated a modernizing process that was very similar to what Headrick (1988) terms "selective modernization." The term describes a process characteristic of nineteenth-century colonial practices, which favored the development of transportation and telecommunication networks over other types of infrastructure.

The tensions inherent in selective modernization become clear when one examines water supply, sanitation, and irrigation projects. Although the colonial powers of the nineteenth century (Britain, France, Spain, Belgium) gave top priority to the development of water supply and sanitation projects at home, financing such projects in their colonies was not considered to be a profitable or desirable investment. The development of railroads and telecommunications in the colonies provided direct trade benefits to the colonizing power, and facilitated further colonial development. But water supply and irrigation projects were expected to yield neither money nor symbolic capital for colonial regimes: "an irrigation system is neither dramatic nor romantic. It takes much longer to build than any other public work and provides no return until it is almost completed.... Irrigation has few poets and publicists to sing its praises compared to ... railways" (Headrick 1988, 194). Sharma (1951) makes a similar argument with reference to the British colonial regime in India. He argues that the construction of railways in India was prioritized over the construction of canals because "the former facilitated British trade in India, whereas the latter benefited agriculture, for which the British trader had little or no concern" (Sharma 1951, 195). Adding to this analysis of the relationship between colonial rule and lack of priority for water supply and irrigation systems, Swyngedouw (2004) also documents that it was only after 1830, when Ecuador became independent from Spanish rule, that urban infrastructure projects there received attention and funding.

In line with the restrictions of selective modernization experienced by colonized territories worldwide, Greece's urban water supply projects were also caught between the Scylla of not featuring on the list of interests of foreign capital, and the Charybdis of lying beyond the financial abilities of the Greek state. The social-cultural perceptions around water also proved a significant barrier for attracting even petty private capital to invest in water infrastructure projects. The public perception of water as a public good and a human right, rather than a commodity, was very strong. The first proposal for a small-scale water supply project tendered by a private company in 1839 was characterized by the municipal authorities as "an excessive and hideous speculation" (Script 1904a; see also Paraskevopoulos 1907, 30; Gerontas and Skouzes 1963).

\section{Enter the Greek Engineering Community}

Although foreign capital remained indifferent to water supply projects, the growing Greek engineering community saw in these projects a field still free from the invasion of foreign experts and an opportunity to take on a leading role and construct water engineering as their own scientific proficiency. In 1889, a year of severe drought for Athens, the public works engineer, Eng. Aggelopoulos ${ }^{4}$ published a project proposal for channeling 
water into Athens from Lake Stymphalia, which is located in the mountains of the Peloponnese. This was the first proposal for watering Athens that did not advocate further restoration of Hadrian's aqueduct. The proposal triggered a series of reactions, both positive and negative, but, most important, it sparked the imagination of other Greek engineers, who generated a great number of project proposals in the decade that followed (see Kaika 2005). When another drought hit Athens in 1899, the Association of Greek Engineers provided a forum where these proposals were presented and debated. The studies included projects for channeling water from the Melanas River, $200 \mathrm{~km} \mathrm{NW}$ of Athens (proposed by Eng. Maltezos), from the Boiotikos Kifissos River, $300 \mathrm{~km} \mathrm{NW}$ of Athens (proposed by Eng. Tzouras), and from Oiti mountain, more than $500 \mathrm{~km} \mathrm{NW}$ of Athens (proposed by Eng. Aggelopoulos). Dr Bechmann, the Director of the Parisian Water Services and Professor of the École Politechnique des Ponts et Chaussées, was invited by the Greek state to evaluate these proposals. In his report of 2 December 1900 (cited in Paraskevopoulos 1907, 443), he rejected on the grounds of safety all projects that involved dam constructions, and favored the Lake Stymphalia and the Boiotikos Kifissos proposals. He concluded, however, that the cost for either of these proposals (estimated at 36,500,000 dr.) was prohibitive.

Greek engineers would also occasionally combine their training with entrepreneurial skills and liaise with petty domestic or diaspora capital, or engage their own petty capital in promoting small-scale/low-cost water supply project proposals. ${ }^{5}$ However, none of these proposals received serious attention from the national government or the municipality, and despite the plethora of proposals, the main works carried out between 1890-1906 still consisted of repairs to Hadrian's aqueduct. These repairs, though, were soon faced with a new challenge: with the expansion of the city, the excavation works were no longer taking place in empty fields but in the middle of urban settlements. The inhabitants of these settlements were now protesting and threatening to take up arms in order to stop the works, which they perceived to be an intrusion to their privacy and to their land (Gerontas and Skouzes 1963).

Thus, Athens was marching toward the twentieth century being both modern and underdeveloped: it was well connected to the rest of the country through railway and telecommunication projects funded by foreign capital, it boasted neoclassical buildings funded by diasporic capital, and it was reconnected literally to its ancient veins; all the same, it still lacked an adequate supply of potable water for its growing population. Moreover, the end of the "railway decade" found Greece with 50 percent of its national budget allocated to servicing external debt, a situation that culminated in the bankruptcy of the Greek state in 1893 (Clogg 1984). During the same period, one-sixth of the impoverished Greek agricultural population emigrated to the United Kingdom or Egypt (Constantinou and Diamantides 1985). It was only after World War I that the reconfiguration of the economic and geopolitical landscape turned water infrastructure projects in Greece, for the first time, into an attractive option for western capital expansion.

\section{The Geopolitics of Producing an Urban Oasis}

At the end of a tumultuous political period that followed Greece's bankruptcy (1893), and while Greece was continuously embroiled in war with Turkey, Eleftherios Venizelos, leader of the Greek Liberal Party, came to power in 1910 and embarked on an extended program of domestic reform. This included land reforms, the reduction of interest rates, the introduction of minimum wages, and the official recognition of trade unions (Clogg 1984; Sloulatos, Dimakopoulos, and Kondis 1984). These reforms dealt a substantial blow to the residues of the Ottoman system by breaking up large estates (Tsoukalas 1981) and by openly supporting a small, but growing and educated, middle class and an emerging shipping-based commercial and industrial bourgeoisie. After the end of the Balkan Wars (1912-1913) Greece expanded its territory by 70 percent, and its population from $2,800,000$ to $4,800,000$ (Clogg 1984). Securing a large degree of domestic consensus, Greece's new liberal political leadership was committed to the establishment of a state-led market economy. However, the warfare did not end with the Balkan Wars. In 1917 Greece entered World War I (1914-1918) on the side of the Allied Forces.

The end of World War I brought an important shift in the geopolitical alliances and power networks operating in the so-called "Near East." As Britain's international financial role deflected from international creditor to a debtor, both Britain and France-the "Entente Cordiale" that used to act as the "protector" of the Near East-retreated into their respective "home" territories. New York, instead of London, became the "center of the world" and the United States assumed "the role of the protector of colonial regimes" in the Near East (Psiroukis 1974, 174; Hebbert 1998, 139). Consolidating its new geopolitical and economic role in the area after World War I, the United States signed a new set of trade 
agreements with Greece, favoring American investment in Greek territory. Further, a series of domestic economic reforms allowed shared equity companies on Athens's stock exchange for the first time, and permitted foreign shareholding in Greek banks.

It was through these important geopolitical and economic changes that water supply and irrigation projects became attractive for the first time as a means of expanding the base of western capital. During this period, the United Kingdom turned India into its "laboratory of hydraulic engineering" as part of its efforts to escape its own financial crisis (Headrick 1988, 196). The United States did the same by getting involved in big infrastructure projects in the Near East and South America. In view of the interest of American capital in urban infrastructure projects, the improvement of Athens's water supply returned to the foreground. The new domestic and international reconfiguration of power provided a new material context within which the double vision for modernizing Athens could be pursued.

\section{The Marathon Dam Project: A "Patriotic" Investment}

In 1918, shortly after the end of World War I, an American consortium of fund-holders submitted (via the Bank of Piraeus) a proposal for the construction of a dam and an artificial lake at Marathon (Figure 2). The Greek government approved the proposal, and a team of sixteen American engineers was appointed under the supervision of Walter Spear, chief engineer of hydraulic works for New York City, to produce a detailed feasibility study on the Marathon dam project. It was the first time that a large-scale engineering project for water supply received full financial backing, as well as a full feasibility study. Everything indicated that the project would go ahead. However, the outbreak of war between Greece and Turkey in Asia Minor (15 May 1919) stalled the implementation of these plans. The end of this final war episode with Turkey had disastrous social economic and political consequences for Greece and remains inscribed in the Greek popular imagery as "the Asia Minor Disaster." The treaty of Lausanne, signed in July 1923, redefined the borders of the Greek state and imposed International Financial Control on Greece. The subsequent Lausanne Convention ordered a "compulsory exchange of Turkish nationals of the Greek Orthodox religion resident in Turkish territory, and of Greek nationals of the Moslem religion resident in Greek territory" (Clogg 1984, 120). This resulted in the inflow of 1.3 million people of Greek Orthodox religion from Asia
Minor into Greece, in exchange for half a million Moslems from Greece, who resettled in Turkey. The population exchange generated an explosive refugee problem. The population of Athens alone doubled to 704,247 inhabitants between 1920 and 1928 (Leontidou 1989, 132) and the water resources available dropped to approximately $10 \mathrm{~L}$ per capita per day (Table 2).

In 1923, the Ministry of Transport ordered a scientific committee, headed by T. Genidounias, to assess all projects for water supply that had been proposed since 1889. The committee produced a five-volume report, which concluded that proposals for channeling water into Athens from water-rich areas were not viable options given the high cost and meager results anticipated. The report also rejected proposals to drill for water and concluded that the only solution left, "the last resort" to which Athens could turn, was the revived 1918 American proposal for a dam and reservoir at Marathon (Genidounias, Koumousis, and Loprestis 1923, 175). The report calculated that the cost of the Marathon project would be 3.6 to 6 times less than that of an equivalent construction at any other location.

The government proceeded by announcing a restricted public competition for the Marathon project, and the successful bidder was Ulen \& Co, a New Yorkbased multinational construction firm, with thirty years of experience in large-scale infrastructure projects in developing countries. On 22 December 1924, the Greek government, Ulen \& Co, and the Bank of Athens (the contract negotiator) signed the contract for financing and constructing the water supply works, which included the construction of a dam, a conveyance pipe of $21.5 \mathrm{~km}$, a treatment plant, and a distribution network. The contractual agreement was approved by the Greek Parliament, which also ordered the establishment of the

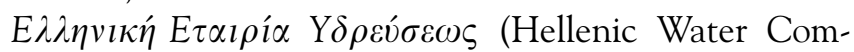
pany, hereafter "EEY"). The EEY was to serve as financial administrator for the project, supervise the construction works, and manage the water supply.

The project's total budget of US $\$ 10$ million exceeded the stock and reserve funds of the National Bank of Greece (1926), but was nothing more than an averagesize investment for Ulen \& Co, which at the time held contracts for constructing water and sewerage networks in Brazil and Colombia, public highways in South America, and railroads in Persia (Ulen \& Co 1930). Ulen $\&$ Co provided immediate cash flow for the implementation of the project, but the project was, in effect, financed by the Greek state in the form of a US $\$ 10$ million loan, which inevitably increased and worsened the country's debt. The loan would be repaid to Ulen \& Co in annual installments of US\$1 million. 
The Greek government proceeded with a number of measures that would guarantee repayment of the loan. First, it issued state bonds for a value of US $\$ 10$ million that were floated on the markets of Athens, New York, and Cairo. In an attempt to attract investment from local and diaspora Greek capital, the bonds were advertised not only as "the best, safest and most beneficial investment," but also as the "most patriotic investment that a Greek can ever make ... since the support of large scale infrastructure projects ... guarantees the country's economic and social progress" (Empros 1926a). A second tactic adopted to guarantee a steady flow of income for the repayment of the loan was the decision to make connection to the water supply network and the installation of water meters compulsory for all new households. The installation of water meters, however, generated great public upheaval because the idea of water as a commodity that would be metered and sold in the market was alien to the Greek public (Empros 1930a, 1930b). Given the public discontent, the Greek state retained the right to define the rates for water charges, in order to secure low prices and maintain the "public good" character of water. A third, equally controversial means of securing repayment of the loan was the introduction of Law 10/3316, which implemented a new "water supply tax" on real estate income for properties in Athens, Piraeus, and environs (Empros 1925c). The government estimated that full repayment of the Marathon loan from real estate taxation alone would necessitate a threefold increase of real estate tax rates. Rather predictably, this proved to be an extremely unpopular measure. Bowing to pressure from the powerful lobby of land and property owners, the government finally ruled the new taxation law to be "unfair" and modified it by (a) reducing the percentage of "water tax" on real estate; (b) introducing an increase in rent prices that would "reflect" the new tax regime; and (c) deciding that the full repayment of the Marathon loan would be covered from the country's domestic budget. The justification for this last decision was that "The water supply of Athens benefits not only real estate owners in Athens and Piraeus; it benefits the country as a whole. Thus, it would be unfair if real estate owners were asked to take the full brunt of repaying the loan, especially since they will also carry the additional economic burden of paying for their water supply" (Empros 1925c).

The new "water tax" was eventually set at 3 percent over the annual real estate income but the returns were nowhere near enough to service the loan. In effect, the state had decided to subsidize not only public water supply by keeping the prices low, but also real estate owners by not taxing in full the increase in the value of their property that the connection to the water supply network would bring. Apart from servicing the loan, the Greek state also had to secure the payment of an annual fee of $\$ U S 65,000$ to the EEY, the management company, in order to cover its operating costs. This fee, which was stipulated in the contract with Ulen \& Co, was the price the Greek state had to pay in order to maintain its right to set water prices at publicly acceptable levels (Eleytheria 1961). However, with low tax rates and low water prices, repayment of the state loan proved very difficult indeed. When the privately owned EEY became a public utility company in 1980 (and was renamed "Е.Y $\Delta$ А.П"), the interest on the initial loan had still not been repaid in full. When, in 1999, as part of a privatization process, E.Y $\Delta$ A.П. floated on the stock market, it still carried US $\$ 2.4$ million of debt from that original loan (Kallis and Coccossis 2000; Kaika 2005).

\section{The Midas Touch: Importing American Capital, Expertise, and Working Practices}

The contract signed between the Greek state and Ulen \& Co was characteristic of the new trade agreements between Greece and the United States, and of the expansion of U.S. capital into the Near East. However, handing over the city's water resources to foreign private capital and management went against the dominant perception of water as a public good and national heritage. Part of the press talked about "a dubious contract between the state and a foreign company" (Rizospastis 1924) and the Prime Minister had to make a public announcement to reassure the public about the future of "their water" (Empros 1925b). Despite public discontent, the government maintained that American financing was the only means to deliver a permanent solution to the city's water supply problem. In an authoritative front-page article, appropriately entitled "Days of Thirst," the state economist Dr. Vellianitis asserted the importance of persevering with the Marathon project, despite doubts, complaints, and grievances. In that article, Dr. Vellianitis severely criticized Ulen \& Co, accused the company of having failed to deliver the promised immediate solution to Athens's water problem, bemoaned the increase in water charges, and commented negatively on the sumptuous luxury of the company's central offices, which, according to the article, was enjoyed "at the expense of Athenian taxpayers." However, the article concluded unexpectedly in favor of the Marathon project and its U.S. contractors: "The contract with Ulen has one very important positive effect: it brings Greece in touch with American capital. ... This cooperation with the USA, who during 
the [First World] War attracted the gold of very important European states, will prove valuable for Greece in the future" (Empros 1926b).

At the gala event held at the Town Hall of Athens to celebrate the signing of the contract, Ulen \& Co's representative noted that "this contract is only the beginning of a closer ... economic, technical and trade cooperation between the two brother democracies" (Empros 1925a).

But it was not only capital that Greece imported from the United States with the Marathon contract. Scientific know-how and managerial expertise were also part of the package deal. Although Ulen \& Co honored its agreement (as ruled in the original contract) to employ manual workers of Greek nationality, the vast majority of the management and scientific personnel employed on the project were Americans (Empros 1926c). The company also introduced novel U.S. working practices. Of the 3,000 wageworkers employed at the Marathon site (Figure 3), 900 were offered accommodation in "comfortable living quarters, gratis, in houses equipped with electric lights, screened doors and windows and heated by wood-fired stoves. ... Palatable and nourishing meals are fed to the laborers at 20 drachmas ( 25 cents) for 3 meals a day" (Water Supply and Sewerage Corporation of Athens 1995, 13).
Both the scale of the project and the working practices that Ulen \& Co introduced were new to the Greek public and to Greek workers. Greece had emerged out of the Ottoman Empire in the early nineteenth century as "a land of peasants" (Koliopoulos and Veremis 2003, 182), and until the First World War, agriculture was still occupying 65 percent of the country's population. In 1920, 91.7 percent of Greece's industrial sector consisted of small workshops of between one and five workers, and a mere 1.4 percent of the country's workshops employed more than 25 workers (Zolotas 1964; Koliopoulos and Veremis 2003). Seen in this context, it is hardly surprising that the Marathon enterprise was met with reservation on the part of Greek trade unions. Apart from being resentful of the fact that Greek workers had to work under American executives, trade unions were also mistrustful of Ulen \& Co's "quasi-Fordist" industrial practices that were alien to the local small-scale industrial sector. The voicing of the trade unions' concerns added to the general public distrust regarding the management of Athens's water supply by a foreign company, and to the general discontent about the increase in water prices. The public mistrust became so strong that Ulen $\&$ Co deemed it necessary to quell public opinion. To this end, the company invited journalists to visit the Marathon construction site and report back to the Greek

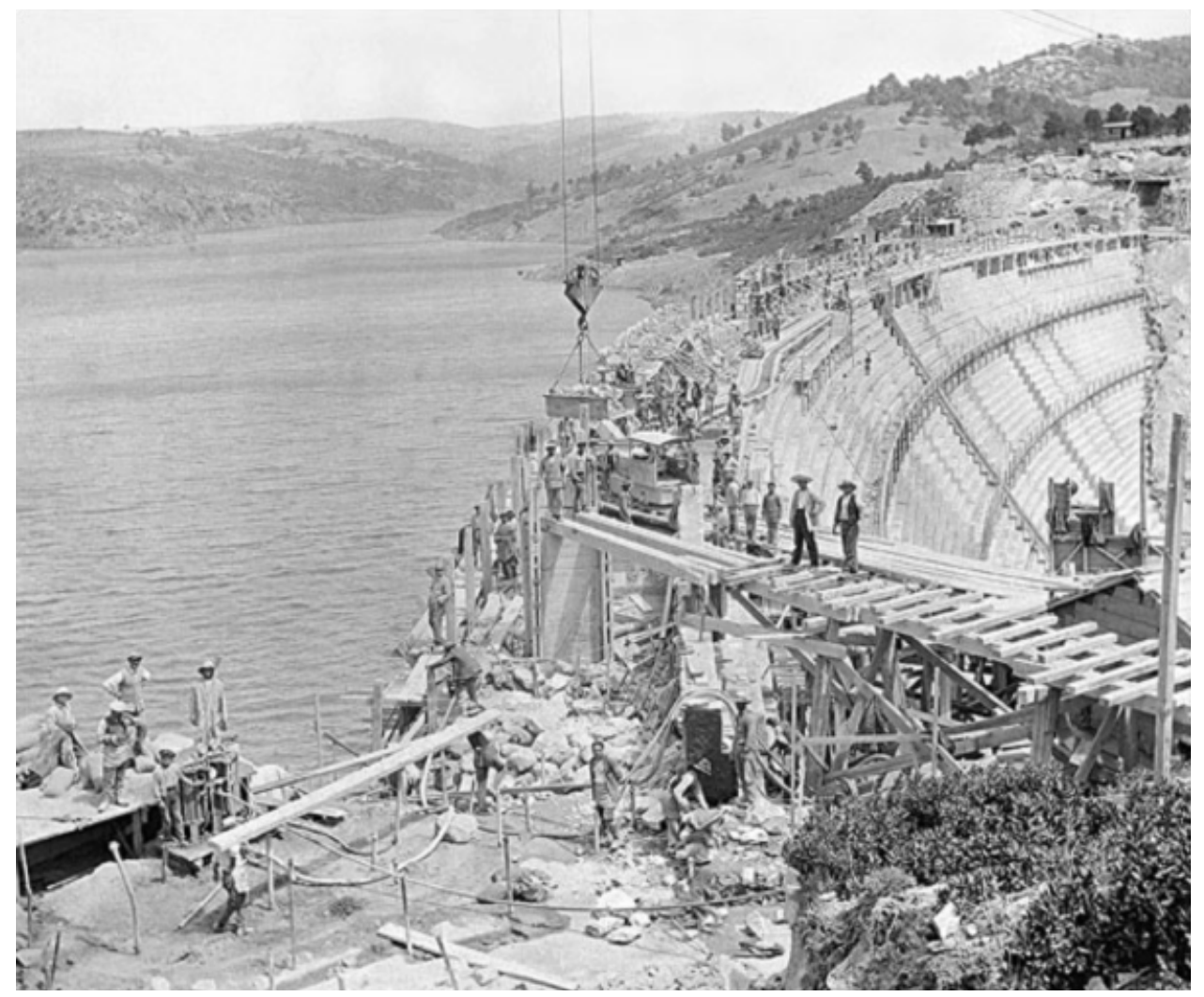

Figure 3. The Marathon dam under construction in 1928. (Source: Photographic archive, Water Supply and Sewerage Corporation of Athens 1995). 
public. The reports were a mixture of journalistic rhetoric and the company's own words:

How can a company that fulfils all its promises, offers jobs to over 1,500 Greek families, and works towards your civilization and progress ... with undisputed conscientiousness ... be faced with ... complaints and accusations? ... Those who try to poison the Greek public opinion against the company with unsubstantiated rumors and allegations are leftist workers and people who consider the presence of American capital in Greece to be against their own interests. ... If, however, these same people were to visit the Marathon site, observe the construction works and the living and working conditions of the company's employees ... they too would be able to confirm the abiding interest with which the American executives tend to the needs of their workers, and the care with which they oversee the construction works. ... We are convinced, these people would return from this didactic excursion [to Marathon] with their minds changed and they would resolve to talk less and work more in the future. It is high time the blabbermouths shut up and bowed in front of the Divinities of Work and Progress. ... For while they are wasting their time manufacturing rumors, Ulen \& Co is piercing the rocks of Parnitha day and night in order to deliver, any time now, one of the elements of civilization. WATER.

—(Empros 1928)

The article's pedantic attitude is striking, yet typical of the discourse and philosophy of 1930s industrial paternalism. Indeed, the last part of the article reads like a manifesto declaring the benefits of both industrial paternalism and colonial rule:

The company responds to the workers' needs with affection and care, and spends generously in order to improve the workers' welfare. ... These activities are proof of the humanism that characterizes the noble Americans, a humanism that we wish our own [Greek] entrepreneurs would also cultivate in turn. ... When, instead of hatred from the part of the employee towards the employer, there is mutual love and care (something that is definitely present in Ulen's case), the company gains strength and unity, which assist it with completing the colossal works it undertook at Marathon.

—(Empros 1928)

Despite the criticism it received, the company's industrial paternalism proved very popular with the majority of the impoverished Greek construction workers. When the project's Welfare Committee was dismantled after the completion of the dam and artificial lake, the remaining 400 workers were dismayed that the company ceased to provide food and health services. The workers issued a public announcement on 20 November 1929 pleading with the Ministry of Transport to act as their ambassador and request that the company reestablish the Welfare Committee that:

used to guarantee healthy and economic food ... saved time for the workers, which was also valuable for the company.... and helped replenish the workers' strength. ... [The provision of food for the Marathon workers] is not too much to ask for, if we take into account the fact that all it takes to satisfy the hunger of Greek workers is a piece of stale bread and an onion.

-(Empros 1929)

Despite the controversy and the debates around its production, the Marathon dam contributed a great deal toward realizing the collective geographical imagination of producing Athens as a western metropolis. As the previous sections have indicated, it took not only plans, debates, and social and political struggles, but also a change in the international geopolitical configuration before this geographical imagination could start taking material form. After the completion of the Marathon dam, and for the first time in its modern history, Athens had adequate water to quench the thirst of its population, and to complete the sanitation projects that would place it on par with other sanitized European cities (Table 3). But what had happened in the meantime to the other, equally powerful, geographical imagination of modernization-the one that identified modernizing Athens with reconnecting it to its classical past? The introduction of progress and technology could have made this dream obsolete, a thing of the past. Still, as discussed in the next section, this vision was not abandoned with the introduction of technological progress. As in other instances of modernization across the Western world (Daniels 1993; Atkinson and Cosgrove 1998; Caprotti and Kaika 2002), in Greece too the past became incorporated in unexpected ways in the material production of the future.

\section{Dams as Symbols of Modernization: The Iconography of the Dialectics between History and Progress}

"Oh yes! Ultimately, the dam had a deep consciousness of its purpose! It must have been so well aware of the fact that it was a dam, a fatal existence, a dividing existence, in order to be able to show itself off in front of the Engineer the way it did that night."

—Plaskovitis (1961)

The Marathon dam was a genuine Promethean project - the biggest construction implemented in the 
Balkans at the time and one of the largest dam projects in Europe (Figure 4). At the ceremony for the inauguration of the construction works on 31 August 1926, the Prime Minister ignited the first stick of dynamite, and one of the government's representatives toasted to the moment when "the issue of water supply that has been tormenting Athens for over 40 years, is about to be solved, thanks to the practical American mind" (Empros 1926d). The dam became the symbol for a new era of modernization and signaled the materialization of the first geographical imagination for Athens: its connection to the West through progress and technology. One year after the inauguration of the project, the supply of water in Athens reached $500 \mathrm{~L}$ per second, and per capita availability increased from $10 \mathrm{~L}$ to $18 \mathrm{~L}$ per day (Table 2 ). From that moment on, water availability, as well as water consumption levels, would increase quickly (Table 3). As part of the same sanitation project, municipal garbage collection was introduced in 1924, and in 1928 the sewerage works were completed, relieving the city of its putrid "black lake" (Mpiris 1996, 300). From 1926 onward, all new buildings in the city center were obligatorily connected to the water supply network and all new houses were fitted with bathrooms and toilets. The construction of the dam contributed greatly to Athens becoming a sanitized, rationalized western metropolis. The quest to modernize Athens via westernizing it, seemed to be gaining momentum over the quest to re- connect the city to its ancient past. Still, this decidedly modern project did not fail to pay its dues to the city's ancient history. The dam unified both visions for modernizing Athens. Its location and iconography, as well as the discursive practices that accompanied its completion, turned it not only into a symbol of modernization but also into an emblem of the cultural links between modern and ancient Athens.

First, the site chosen for the dam (Figure 5) already held a heavily charged historical meaning. Marathon is the plain of northeastern Attica in which the Athenians had won a definitive victory against the Persians in 490 BC. The war of the Greeks against the Persians had become known in the ancient world as the war of the Greeks against "the barbarians." The choice of the ancient battlefield for the location of the dam offered a link, at a symbolic level, between the victory that ancient Greeks won against "the barbarians" and the victory modern Greeks won against an equally "barbarian" nature. In the words of Gerontas and Skouzes (1963, 132), the construction of the dam signified the final victory against a nature-induced water scarcity that had "tormented the capital of Greece and its inhabitants, who had endured, patiently and resignedly, like a new Tantalus, the daily misery of lack of water."

But the desire to celebrate the link between ancient and modern Athens at a symbolic and iconographical level did not end with the location choice. In an effort to

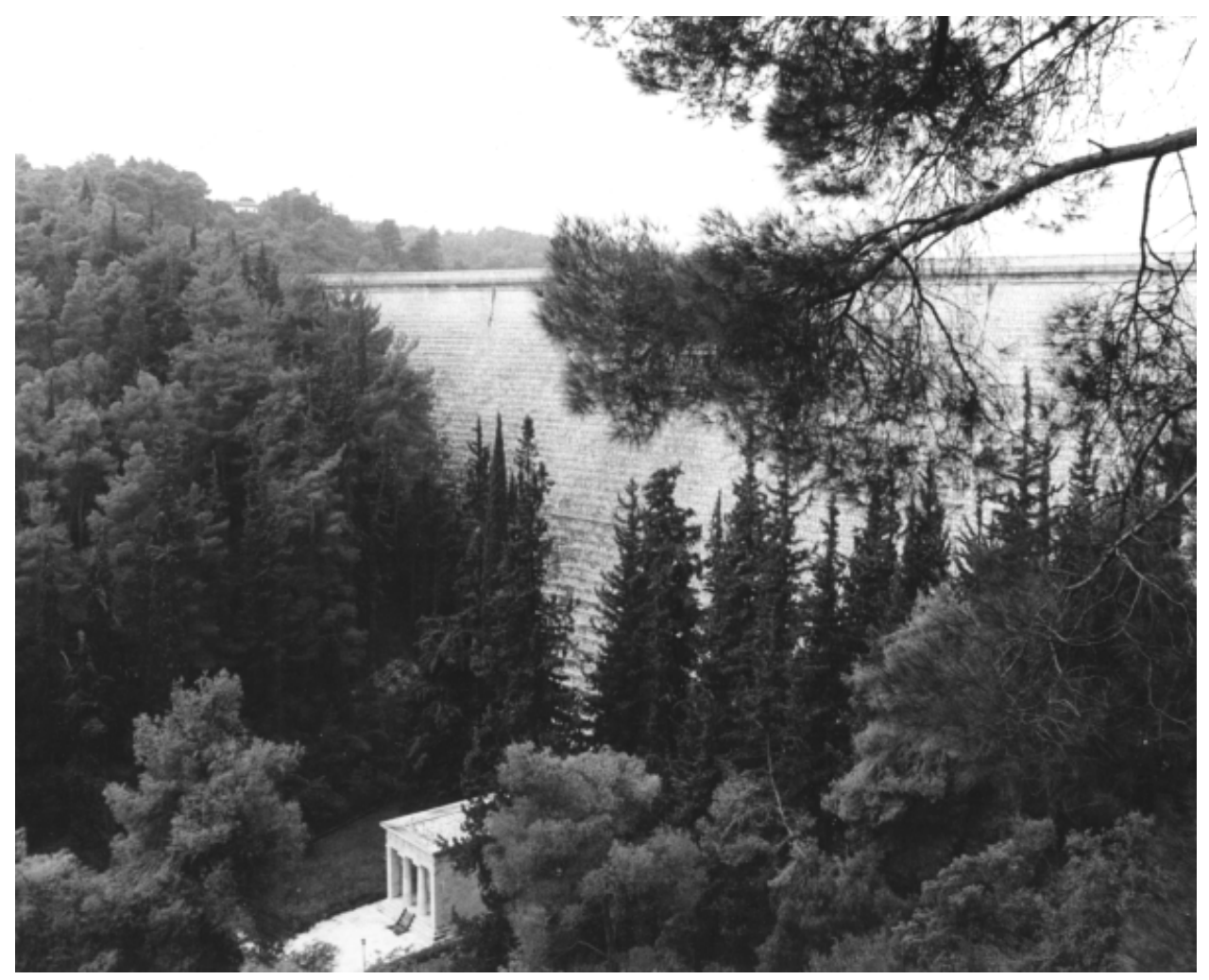

Figure 4. The Marathon Dam today; an impressive construction in the middle of an equally impressive landscape. Notice the marble altar at the foot of the dam. (Photograph by George Shoterioo.) 
Figure 5. A view of the Marathon Dam in 1930. (Source: Photographic archive, Water Supply and Sewerage Corporation of Athens 1995).

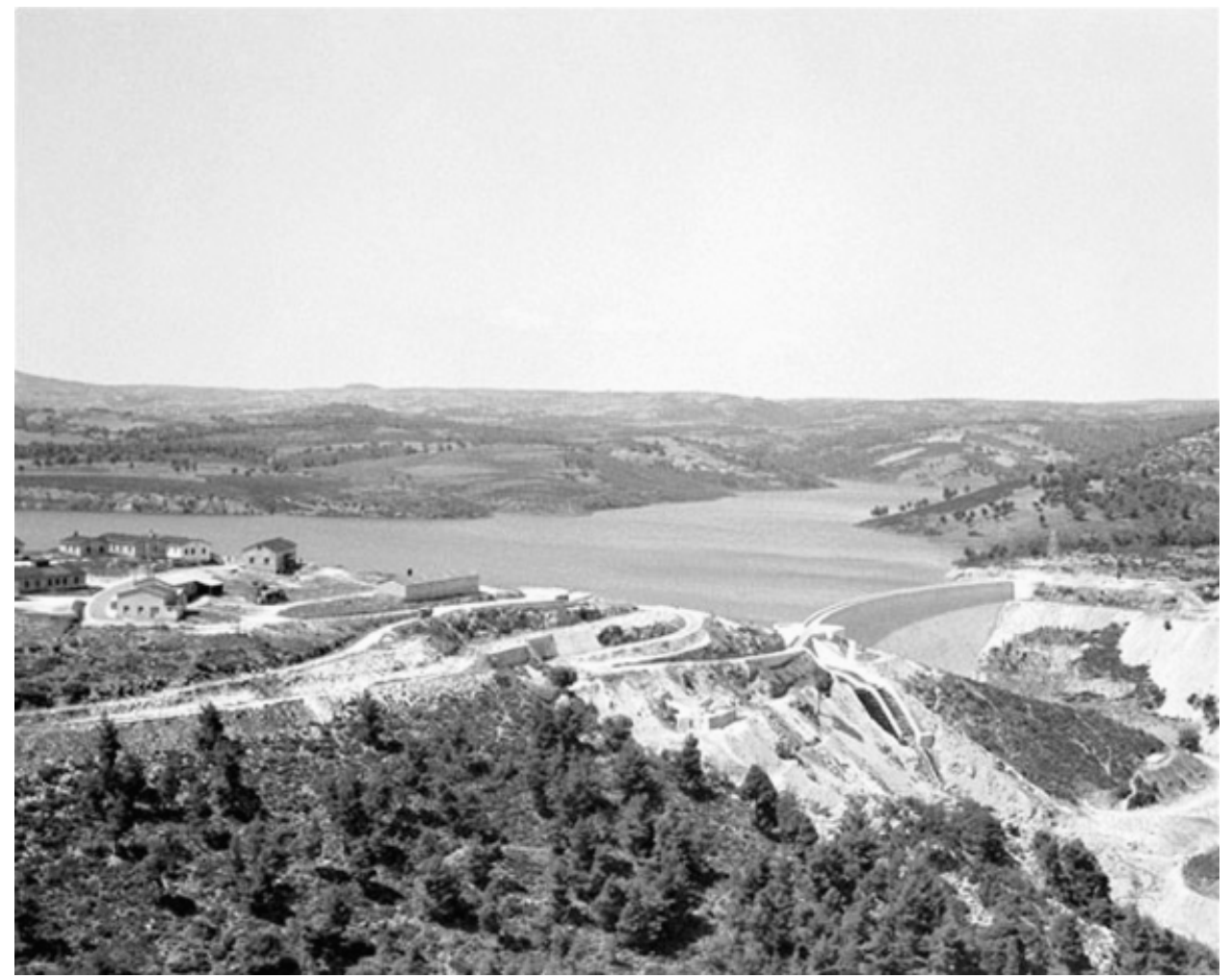

accentuate further the line between past and present, all visible parts of the dam were covered with marble from Penteli, identical to that used by ancient Athenians for the construction of the Parthenon. The marble cladding of the dam was the labor of women, who, in the social division of labor introduced by Ulen \& Co, were considered to be more fit for this decorative job than men (Figures 6 and 7). The symbolism of the marble cladding is striking: the Parthenon was the shrine of ancient Athens, the cradle of western civilization; the Marathon dam would become the shrine of modern Athens, the symbol of a glorious future. In addition, a neoclassical temple was erected at the foot of the dam (Figure 8), an exact replica of the "Treasure of the Athenians." The original "Treasure" was also an altar that had been erected by ancient Athenians at Delphi in $490 \mathrm{BC}$ to thank the Gods for the victory at Marathon. Both temples, ancient and modern, signified the victory of "civilization" over "wilderness." Two plaques, one in Greek and one in English (Figure 9), carved in marble and placed at the entrance of the modern temple, signal this connection between past and future and confirm that the war against nature, a timelong enemy for Athens, had finally been won.

The dam is located $42 \mathrm{~km}$ northeast of Athens, and the moment its water reached the city was also celebrated emblematically within the city itself. A marble public fountain was constructed in the center of Athens, next to Emperor Hadrian's Arch, and near the ancient
Olympieion, the Temple of Zeus Olympios (Figure 10). On the arrival of water from Marathon, a festive public ceremony was held by this fountain, and a document was signed by the representatives of the Greek State and of Ulen \& Co, confirming the satisfaction of both parties with the successful completion of the project. The document affirms the connection between ancient and modern Greek achievements and draws a direct comparison between the Roman Emperor Hadrian, who "implemented the first great water supply works for Athens" (Hadrian's aqueduct) and the modern Greek state, who, with the aid of the American contractor, "implemented the second great water supply project for Athens." The original document, heavily adorned with ancient Greek imagery and meanders, reads:

On this day, in token of their completion, the first waters from the Lake of Marathon have been poured into a fountain constructed near the Arch of the Roman Emperor Hadrian, who constructed the first great water supply for Athens. Ulen and Company, having undertaken the second great water supply in the year one thousand nine hundred and twenty five ... feels pleased and honored to have completed these works which will contribute largely to the future progress of the glorious and time honored cities of Athens and Piraeus.

- (Water Supply and Sewerage Corporation of Athens 1925; original translation) 


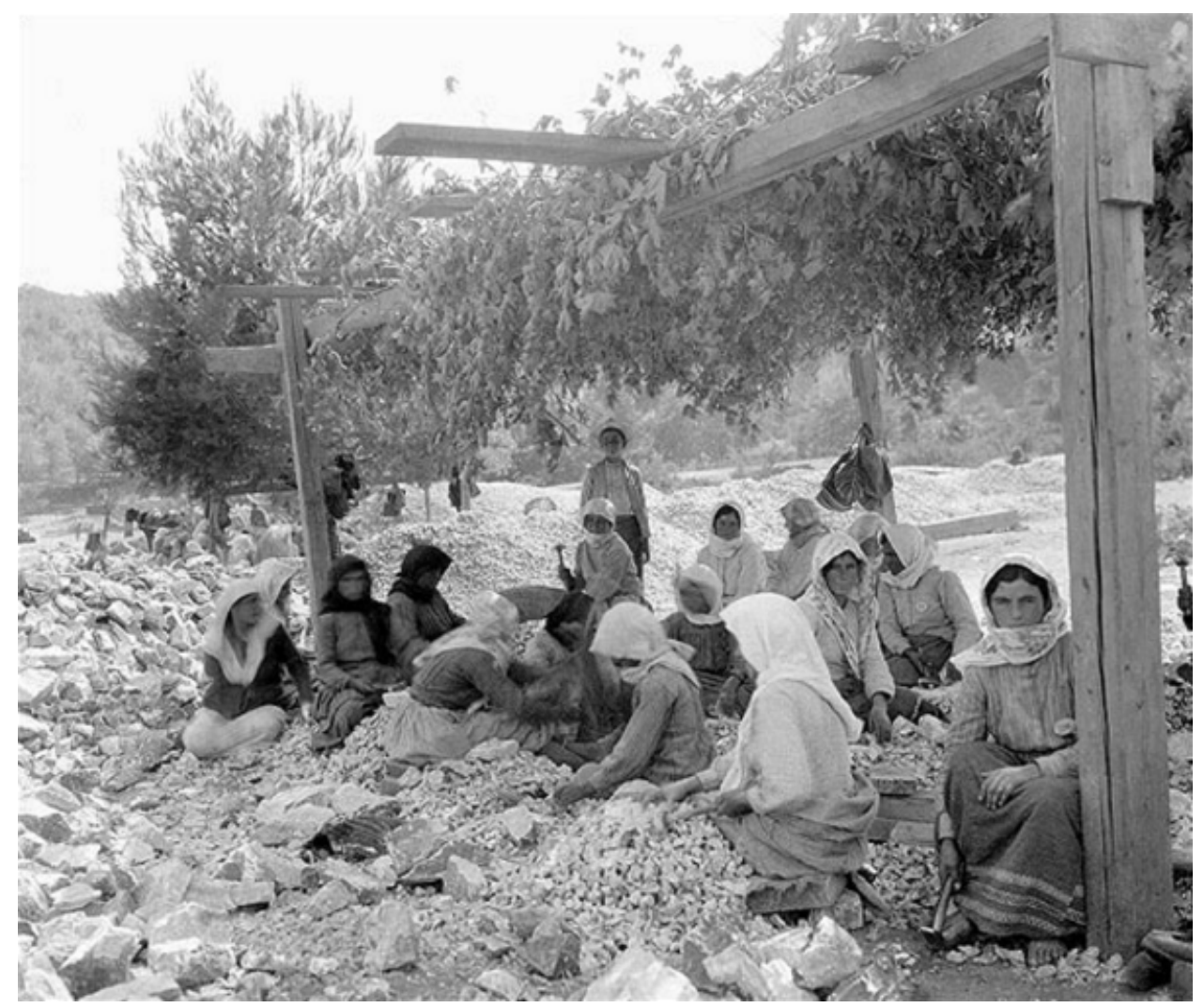

Figure 6. Female labor was used for the "easy" task of veneering the dam with marble. (Source: Photographic archive, Water Supply and Sewerage Corporation of Athens 1995)

As the Marathon dam embodies in its form and function the two visions for modernizing Athens, it serves as an allegory for a country teetering between modernization and tradition, a country eager to mod- ernize (westernize), yet caught in a persistent net of traditional social and cultural relations. During the interwar years, this ideological preoccupation with the past provoked a schism between Greece's "modernists" and

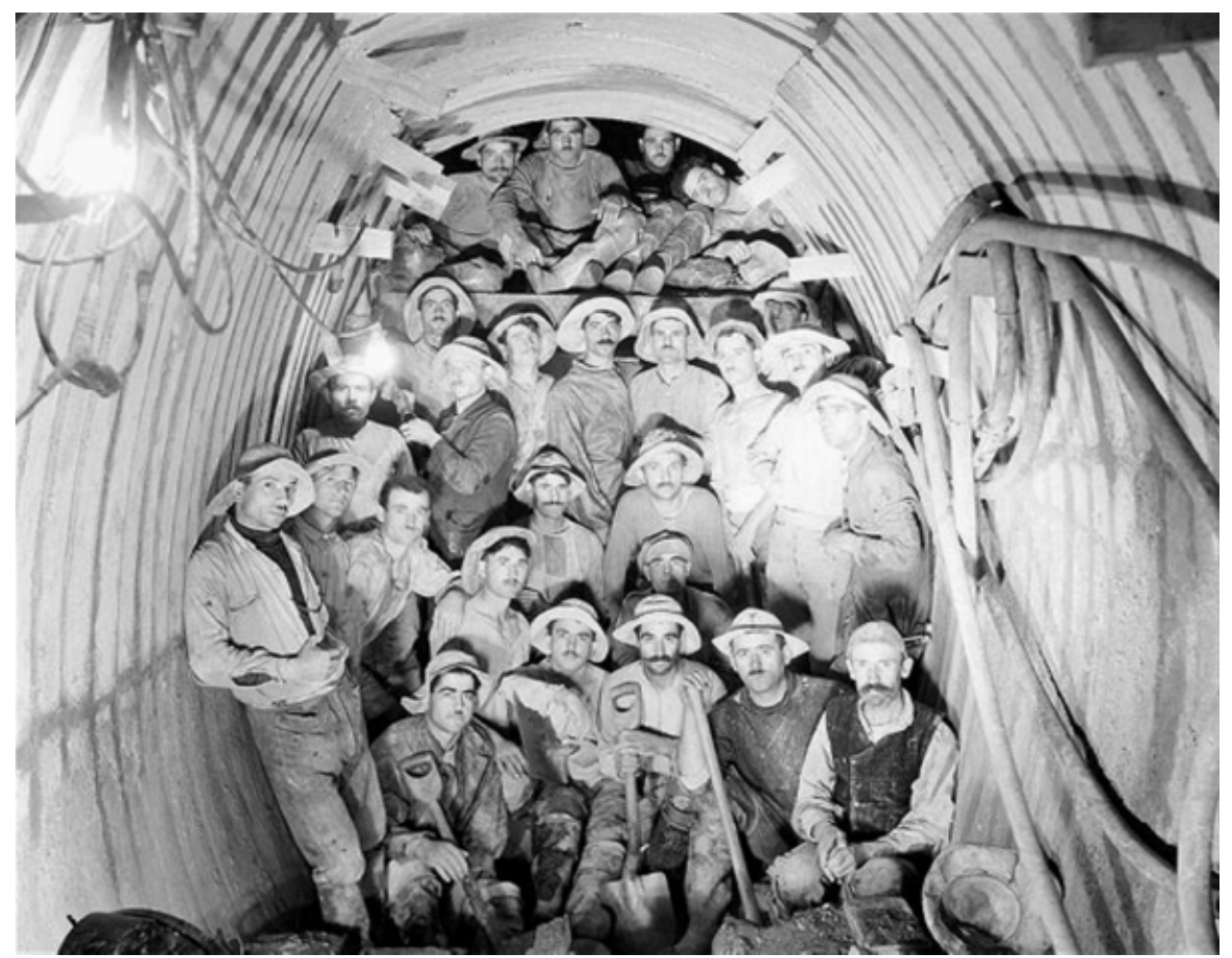

Figure 7. Male labor was reserved for the "harder" tasks involved in the construction works. (Source: Photographic archive, Water Supply and Sewerage Corporation of Athens 1995) 
Figure 8. Linking the past with the future. The replica of an ancient altar (the Treasure of the Athenians) lies at the foot of the modern dam. (Photograph by George Shoterioo.)

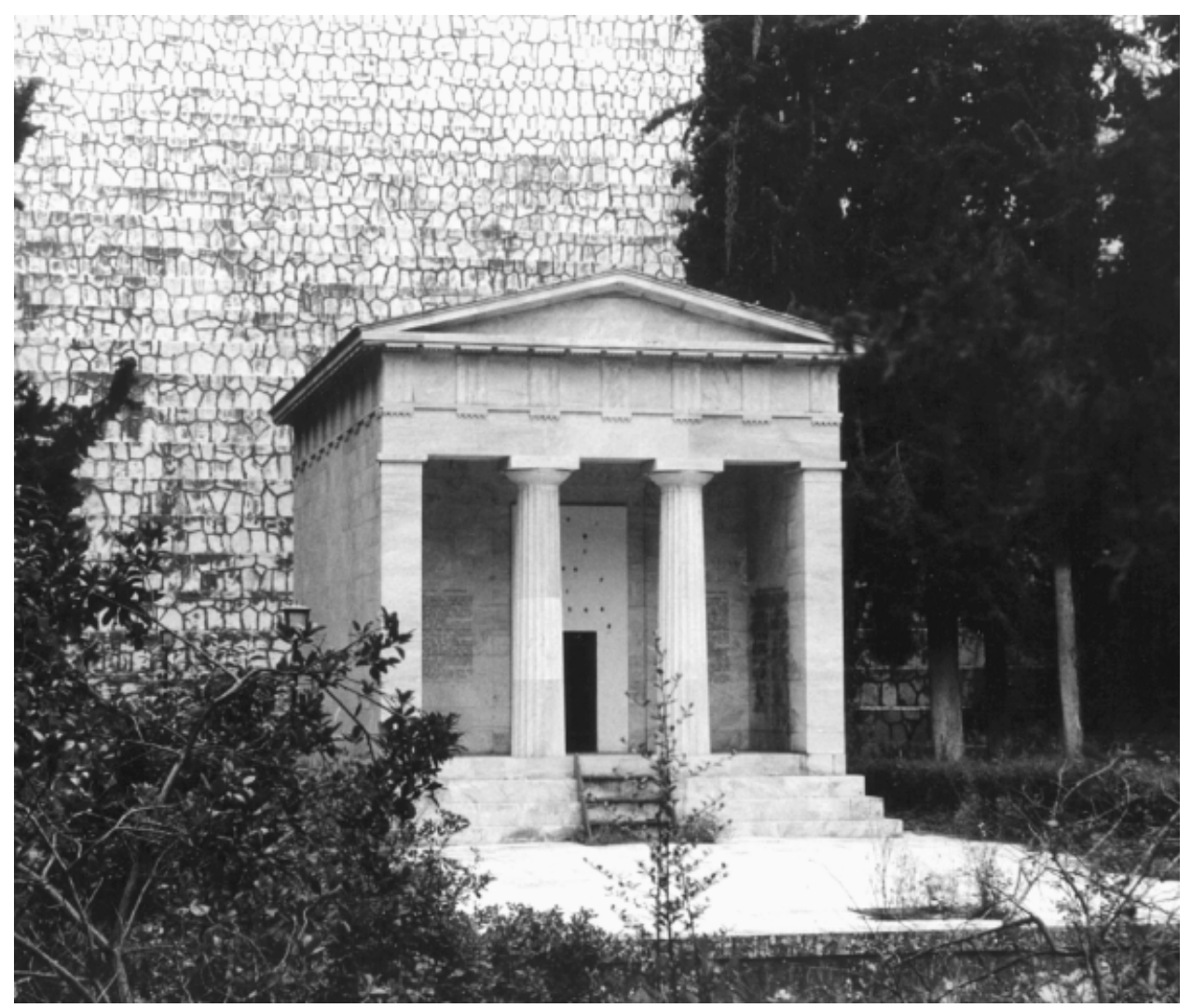

"traditionalists" (Tziovas 1989, 73-93; Kotidis 1993; Cholevas 1998) that manifested itself in the political (conservatism vs. progressivism, monarchists vs. liberals), economic (petty capitalism and entrepreneurialism vs. an emerging industrial and shipping bourgeoisie), and cultural arenas alike (indigenous aesthetics vs. the international style). The adoption of neoclassical iconography for a decidedly modern engineering construction stands as an eloquent representation of this dialectic between past and future, between tradition and modernity, that pervaded Greek politics, society, and culture.

\section{Dignifying Progress and Congealing National Ideologies}

As noted earlier in the article, the fusion of past forms with modern achievements is not an exclusively Greek phenomenon (Tsaggari 1985). During the nineteenth and early twentieth centuries, historical forms adorned not only state buildings and bourgeois homes across the Western world, but also buildings that hosted new technologies and required a new architectural language. Cosgrove, Roscoe, and Rycroft $(1996,549)$ have exemplified how Ladybower's concrete and steel construction (1935-1945) in the United Kingdom's Peak District National Park was "softened by classical detailing" and "hidden under a make over landscaping à la eighteenthcentury English picturesque" that would appeal to a sense of the "national aesthetic." Jeffrey Herf (1984) has analyzed the fusion of technology with romanticism in Weimar and Nazi Germany as part of a "reactionary modernization" that desired to retain a mythologized German culture and national identity. Indeed, the Greek Revival became one of the favorite styles for "softening" technological innovation. A great number of railway and subway stations, factories, pumping stations, power plants, and so forth were built in this style. The Fairmount Waterworks in Philadelphia (early nineteenth century), the Abbey Mills Pumping Station (mid-nineteenth century) and Euston Station (1838) in London, the Pennsylvania Railroad Station in New York (built in the early twentieth century, demolished 1964) are but a few examples of buildings that housed modern technology but were draped with classical ornament. Even buildings and constructions that remained invisible, underneath or outside the city (such as sewers, dams, and pipes), were often adorned with classical trimmings.

It is ironic that historical styles became the early aesthetic pronouncements of the innovations of an era that declared its determination to break irrevocably with history. But the historical forms provided an easy compromise and a conservative solution to a number of 


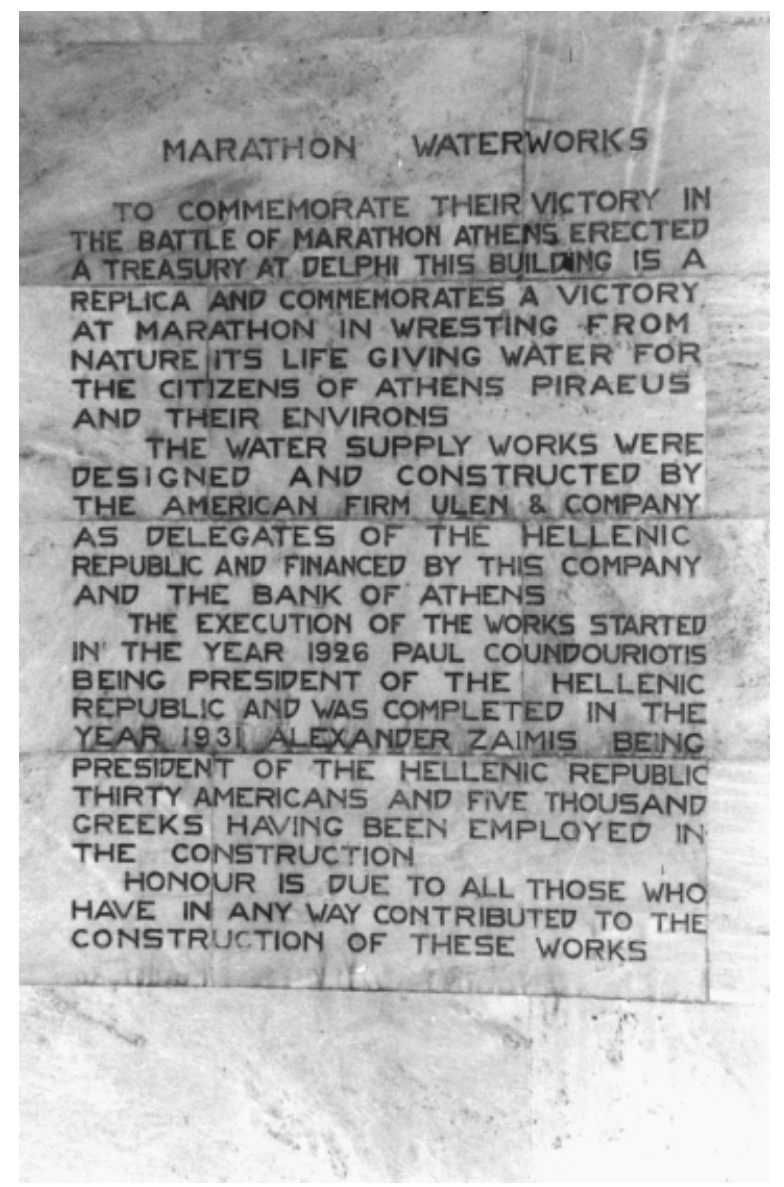

Figure 9. The marble plaque at the entrance of the altar at the foot of the dam reads: "To commemorate their victory in the battle of Marathon, Athens erected a Treasury at Delphi. This building is a replica and commemorates a victory at Marathon in wresting from nature its life giving water for the citizens of Athens.... Thirty Americans and five thousand Greeks having been employed in the construction. Honour is due to all those who have in any way contributed to the construction of these works." (Photograph by George Shoterioo.)

challenges. First, they provided a way out of the requirement to find a new architectural language for new functions. Until the modernist motto "form follows function" became common design practice, "readymade" historical styles would conveniently vest technology's new functions. Second, historical styles assisted in making the massive transformation of socioeconomic landscapes publicly acceptable (Tsotsoros 1995; Cosgrove, Roscoe, and Rycroft 1996, 549). Historical forms were used and presented as an aesthetic antidote to the dehumanizing aspects of industrialization and modernization. Unearthed from a humanistic tradition, neoclassicism and the Greek Revival linked technology, at a representational level, to the origins of western democracy, thereby contributing toward "democratizing" technology and "dignifying progress" (Schorske 1981; Chant 1989; Picon

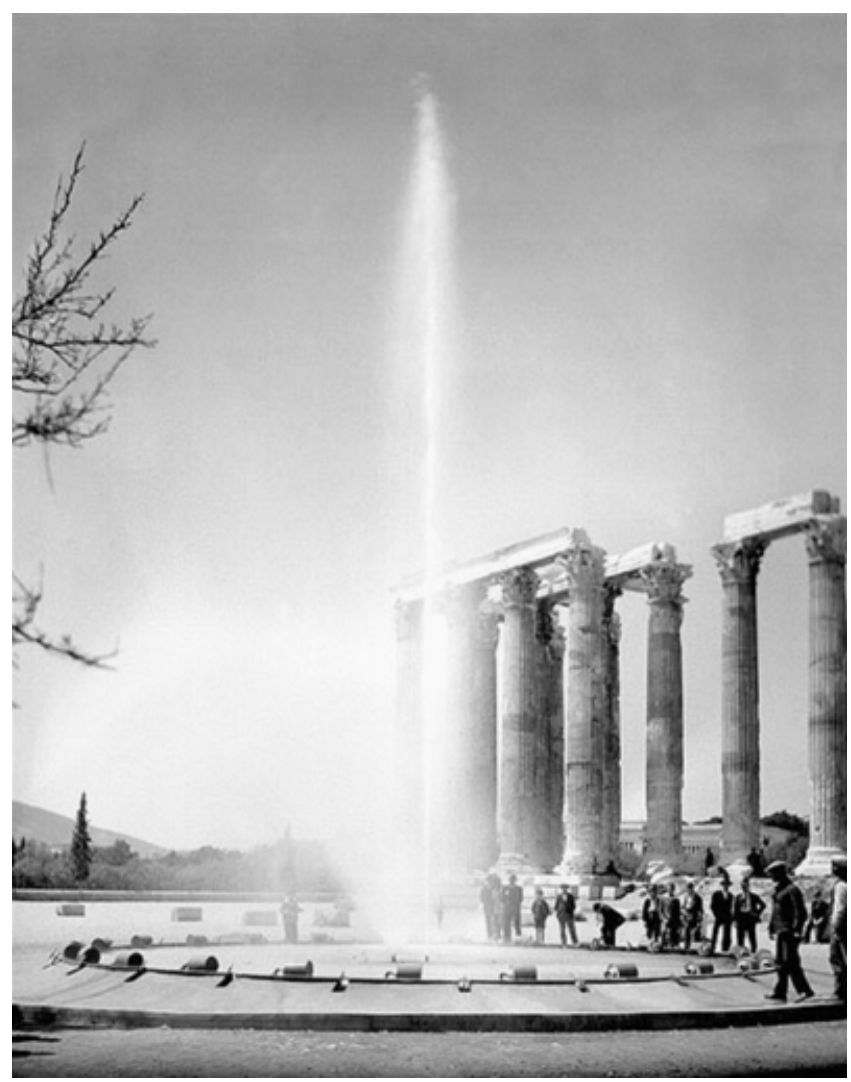

Figure 10. A public fountain was constructed in the center of Athens, between the Temple of Zeus Olympios and Hadrian's Arch. The fountain receives the water traveling from Marathon and marks the plentitude of resources available. The photograph was taken in 1935. (Source: Photographic archive, Water Supply and Sewerage Corporation of Athens 1995).

1992; Kaika and Swyngedouw 2000). Third, the guise of technological achievement in historical forms contributed toward linking progress and technology to dominant discourses of nationhood and patrimony. In the eighteenth and nineteenth centuries ideological constructions of nationhood were centered on the land and the region. For the twentieth century it was technological achievements that featured high on the list of accomplishments of which a nation could/should be proud. Water engineering in particular became arguably the most important aspect of technological innovation through which the geography of the fatherland could be "enhanced" and a nation could realize its full economic, social, and cultural potential. Caprotti and Kaika (2002) examined Mussolini's land reclamation projects in the Pontine Marshes, south of Rome, in this context. Inspired by the Romans, who had tried but failed to reclaim the land, this project produced a techno-nature that would foster economic self-sufficiency, but would also induce national pride for a fascist Italy that succeeded where "even the Romans" had failed. Dam projects in particular, became an 
exemplary symbol around which national ideologies could congeal. Swyngedouw $(1999,2005)$ gives an excellent analysis of the relationship between dam constructions and nation building in Franco's Spain. The dams built under Franco's national hydrological plan were expected to unify the country by solving its "national geographical problem." Along a similar vein, in his beautifully crafted Concrete and Clay, Gandy (2002) contends that the newly completed Kensico dam was designed to inspire "civic pride in the citizens of New York." The Marathon dam was also described as "a beautiful construction, unique world-wide" and an "achievement of which the Greek nation should be proud" (Koumparelis 1989, 75). In a public speech in 1925, the President of Ulen \& Co declared that he felt "very privileged, that 2,300 years onwards [he was] honored with the task to continue the work of the immortal Themistocles, to whom the ancient Athenians had entrusted their city's water supply" (Empros 1925a). With the Marathon dam gleaming in Pentelian marble, and the president of Ulen \& Co gleaming with pride at being appointed as the new Themistocles, the geographical imagination of ancient history as modern truth lived on.

\section{Recasting the Relationship Between Nature and the City and Visiting the Stigmata of a Conquered Nature: A New Way of Experiencing the Countryside}

Describing the relationship between water and the medieval city, Guillerme $(1994,6)$ contends that water had been "subjecting the city to its power by molding it at will, forcing the streets and buildings to adapt to its winding path." Modernity's Promethean Project brought this dependency to an end, as it "freed" the city from the constraints posed on its form and function by nature. In the case of Athens, the Marathon dam was the symbolic first step toward establishing a new status quo in which nature was marshaled in the service of urban development. It signaled the moment when nature's water could be controlled and channeled at man's will and announced a new relationship between nature and the city. After a century of being subjected to water's power, finally Athens was freed and could expand in all directions and forms, which it duly did! (Burgel 1981; Kafkalas 1981; Mantouvalou and Martha 1982; Leontidou 1990; Hadjimichalis 1994; Vaiou, Mantouvalou, and Mavridou 1995, 2000; Giannakourou 2000).

However, the same process that liberated the city from the constraints posed by lack of water also signaled the city's perpetual dependency on the production of (new) nature in order to sustain its life, its form, and its metabolism. Now water not only could, but also had to be tamed, managed, channeled, and redirected in order to sustain the city's growth and expansion over space and in time. While turning the tap inside one's home became the "natural" thing to do to get water (Kaika 2004), looking for solutions to urban water problems outside the city became the norm as water consumption levels kept rising (Kaika 2003).

With their pivotal role in quenching the thirst of growing cities, and the symbolic value that they acquired as hallmarks of technological progress and national pride, dams assumed the status of modern shrines. They became places of pilgrimage and favorite tourist destinations (Cosgrove 1990; Gandy 2002). These dam trips signaled a new way of experiencing "the countryside" and "nature." Green $(1990,80)$ notes that the favorite destinations for eighteenth-century countryside visits were gardens and the estates of the famous, whereas nineteenth-century urban dwellers traveled into the countryside more in search of "wild nature." It could then be argued that the twentieth century's pilgrimages to dams signaled yet another qualitative shift in the way the urban dweller experienced and appropriated the countryside in many parts of the Western world: no longer in search of the beauty of a divine and pristine nature, but in conscious pursuit of the splendor of a man-made, pride-inducing "second" nature (Smith 1984; Harvey 1996; Castree and Braun 1998; Swyngedouw 1999; Demeritt 2001). The twentieth-century countryside visitor was no longer just the alienated urban dweller wanting to transcend his or her urban experience, but also the proud son or daughter of Prometheus arriving to oversee the conquered land. There, in the middle of the transmuted landscape, the urban dweller could trace down the stigmata on a mastered nature that enabled his or her city to function and metabolize (Kaika 2005).

In most European countries, the nineteenth century's romantic quest for a "pristine" nature gave way to the twentieth century's civic pride over a man-made, transmuted socionature. Engineers asserted the landscape aesthetics of large-scale water supply projects long before architects dared to bare the aesthetics of reinforced concrete naked to the public eye. Despite the cladding of dam projects with classical ornament, the transformation of the landscape that accompanied the implementation of these projects was not, and could not be muted. Water engineering became one of the first instances where the "modernist engineering aesthetic" asserted its own beauty. ${ }^{6}$ In the public rhetoric that accompanied the inauguration of such projects, the alteration of the landscape that took place was to be 
commended, rather than lamented, since the loss of rivers, currents, and trees would be handsomely compensated by the gain in water, electricity, and progress. A 1921 article arguing in favor of dam constructions makes precisely this point:

What will become of our idyllic currents [after the construction of dams]? They will of course disappear. Trees will also have to be felled in order to make space for building reservoirs. But the scientists assure us that this loss will be compensated. We may lose our currents and rivers, but we will gain a lake [reservoir]. ... Water is beautiful in all its forms. ... We can even introduce small leisure boats on the lake. ... To be sure, this is not the first time in the history of humankind that natural beauty is sacrificed to social needs ... to the need to supply everyone with water and electricity.

—(Empros 1921)

Unlike eighteenth- and nineteenth-century countryside visits, which were predominantly a middle-class activity (Green 1990), twentieth-century dam visits featured mainly working class families and groups of factory workers. Often these trips were organized and funded by employers, and took the form of pedagogic excursions that would make workers witness what human labor-their labor-was capable of producing. In the same way that objects of mass consumption (from photo-cameras to cars) were admired and desired as fetish objects of modernity, and became the individualized technological sublime (McLuhan and Fiore 1967; Buck-Morss 1995), dam constructions embodied a collective technological sublime, and testified to the success of technology's emancipatory dream that was about to come true and was ready to be consumed. Apart from their indisputable use value in water and electricity production, dams acquired an equally important representational value; they became objects of delight in themselves, signs and wish images of a better society that was yet to arrive (Buck-Morss 1995). The phantasmagoric character of dam constructions came to represent, display, and celebrate the aestheticized dreams and wish images of tomorrow's utopias (Kaika and Swyngedouw 2000; Kaika 2004).

\section{Conclusion}

This article has identified the efforts to water and sanitize Athens, after it became the capital of the modern Greek state (1834), as one of the most important aspects of the production of the city as a modern western metropolis. The construction of the Marathon dam in the 1920s was a landmark in this process. The study of the iconography of the dam and of the discourses that accompanied its construction sheds light on the complex dialectic between materiality and representation involved in the modernist quest to urbanize nature. A decidedly modern project, yet draped in neoclassical forms, clad in exquisite marble, and completed with a neoclassical altar at its foot, the Marathon dam exemplifies (both in form and function) modernization as a continuous and contested process of creative destruction driven by geographical imaginations that have to be continuously adjusted to historically geographically specific materialities.

This dialectic between geographical imagination and materiality is still present in contemporary planning practices, especially in the planning of "pulsar effects," such as "Cultural Capital" bids or "Olympic Games" (Beriatos and Colman 2003). The production of Athens as an Olympic City in 2004 was predicated on the implementation of large-scale infrastructure projects. In the months gearing up toward the Olympic games, Athens was turned into a giant construction site. The momentum of engineering public infrastructure works and the creative destruction they involved was reminiscent of the rigor of nineteenth and early twentieth century modernization projects. However, it was not only contemporary material practices that were comparable to those of earlier times; the wish images that accompanied the production of Athens as an Olympic city were also astonishingly similar to those of the nineteenth century. The official advertising campaign for "Athens 2004" marketed Athens as the Olympic city where "the ancient and the modern come together."

The conceptual backbone of the campaign launched by the Greek National Tourism Organization in the runup to the Athens Olympic Games in 2004 was a playful dialectic between the city's past and its future. One advertisement, for example, pictured a brand new metro station, with shining granite floors and walls decorated with stunning ancient sculptures. The accompanying text, however, undermined the semiology of the picture, declaring provocatively that "in Athens, transportation is stuck in the past." The small print explained the oxymoron: "We tried to build the new subway system as fast as possible, but ... we simply had to make a few stops along the way. You see, we unearthed some fascinating ancient findings and even though we're not all archaeologists, we couldn't help but marvel at them." These findings are now on display in the new Athenian metro stations, once again marrying the city's classical past with its modern future. No matter how hard Athens tries to deliver the future, its past comes to haunt it in every corner. The advertisement concluded: "the new 
subway system moves at the speed of today. But we never forget the glory of the past." Cunningly resonating with nineteenth-century discourses, the past and the present were fused in the project to produce an Olympic future for contemporary Athens.

It is true that the Western world no longer admires technology the way it did in the nineteenth and early twentieth centuries, and it has grown distrustful and skeptical of the modernist myth. Still, it continues to produce wish images, ideologies, and dreams of modernization and to relentlessly pursue their materialization. Either through small-scale ephemeral "urban pulsars" or through large-scale, long-term projects (such as the new Spanish National hydrological plan), urban and nonurban landscapes are being transformed all over again. Dam constructions may no longer be objects of admiration or places of pilgrimage for westerners, and development projects may be greeted with great skepticism, but despite the rhetoric about the end of modernity, development continues in more or less the same logic as it did in the nineteenth and early twentieth centuries.

Moreover, the less-developed parts of the world are just beginning to formulate their own modernist wish images and to pursue their own agendas of creative destruction. One exemplary case of this process is the project for damming the Yangtze river in China, which promises to deliver water and electricity for all and to tame the "dragon" that remained uncontrollable for centuries. It will inundate villages and displace at least one million people whose livelihoods are "in the way" of progress. When completed, the project will produce a transmuted physical, social, and economic landscape. Although the West launched a fierce critique of the project, the logic of this development is in fact identical to that of development projects that were splashed all over the Western world during the twentieth and even the early twenty-first century. Water engineering becomes today a key pivot for China's modernization, as it was for the West in the early days of industrialization. The wish images and geographical imaginations that accompany the Yangtze dam project also resonate the symbolism and rhetoric that accompanied early dam projects in the Western world. The Marathon dam was hailed as the greatest achievement of Greece after the Parthenon; China's leaders portray the Yangtze dam project as the greatest engineering feat since the construction of the Great Wall. The Yangtze project has become a symbol of China's emergence as a major technological and economic superpower, and the successful completion of the dam has become a matter of national honor and pride (Ronning Topping 2000). The mutated landscapes produced by the dam attract tourist visits that resonate the dam visits so popular with westerners during the first three quarters of the twentieth century. Some among China's displaced farmers have now become gondoliers, taking visitors on boat trips over their inundated houses (Watts 2003). The tension between, on the one hand, the geographical imaginations and the dominant rhetoric around the dam project, and, on the other hand, the materiality of its construction, is great, as the full scale of the social and ecological consequences of the project is hard to grasp.

It seems that for both the developed and the lessdeveloped parts of the world, modernization is an ongoing project in which natures, cities, and people are woven together in an inseparable dialectic of creation and destruction. In this relentless project, iconography and discourse play the role of the ideological negotiator between the competing interests that produce contemporary urban and nonurban landscapes.

\section{Acknowledgments}

Many thanks to Erik Swyngedouw, David Dodman, and Alexander Loftus for their comments on earlier drafts of this article. I am also grateful to the editor and the anonymous referees for their thoughtful and constructive comments that helped me greatly with improving the article. Special thanks are due to George Shoterioo for allowing me to use his photographic work and to Ailsa Allen for her cartographic input. Many thanks are due to the Water Supply and Sewerage Corporation of Athens (EY $\triangle A \Pi)$ for their support of the research project and for granting me copyright permission. The research was funded by the Greek State's Scholarships Foundation (I.K.Y.).

\section{Archival Sources}

The following document sets were consulted at the Archives of the National Library of Greece, Athens:

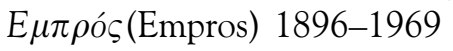

$\Sigma \kappa \rho i \pi \tau$ (Script) 1893-1911

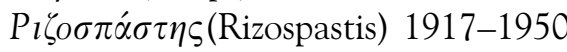

E $\lambda \varepsilon v \theta \varepsilon \rho i ́ \alpha$ (Eleutheria) 1944-1955.

Photographic archive, The Water Supply and Sewerage Corporation of Athens (EY $\Delta \mathrm{A} \Pi)$.

\section{Notes}

1. The origin of the term "Modernity" as well as the chronological boundaries of the historical period that carries the same name remains a source of debate. I cannot rehearse this 
debate within the scope of this contribution. However, it should be noted that the analysis in this article accepts the view that places the beginning of Modernity in the seventeenth century, and sees it as an era characterized by forward looking, a new world view, and a new set of social expectations. For a review of the debate, see Toulmin (1990) and Bauman (1991).

2. Unless otherwise indicated, all translations from Greek texts were performed by the author.

3. Many thanks are due to the anonymous referee who brought this point to my attention.

4. As in some other countries (Germany, France, Egypt, etc.), the engineering profession was (and still is) so highly respected in Greece that the word "Engineer" is used as an honorary title and often features as a prefix to the person's surname.

5. One such case was the proposal tendered by Engineer Fokionos Negris on 24 March 1899 for drilling boreholes on Mt. Lycabettus.

6. Britain makes an interesting exception to this process. There, "the modernist engineering aesthetic ... did not find enthusiastic support." Cosgrove Roscoe, and Rycroft (1996, 549) describe the efforts to "naturalize" the aesthetics of the Ladybower and later the Rutland reservoirs by inserting them into the wider landscape "rather as lakes within a Georgian estate park." In most other European countries, however, engineering artifacts in rural landscapes became one of the first instances where modernism asserted its own landscape aesthetics. In the United States (Allen 1952; Cosgrove 1990), Spain (Swyngedouw 2005), Italy (Caprotti and Kaika 2002), France, and Germany, and France and Germany, dams, reservoirs, and water-pumping machines were proudly displayed in their brutal beauty, with no effort to historicize them by inserting them in a man-made pastoral landscape. The crucial role that financial constraints played in the decision not to implement landscape design projects along with water engineering projects cannot be overemphasized. Although that discussion lies outside the scope of this article, it should be noted that Greece was not alone in being unable to afford landscape design projects in the beginning of the twentieth century. Indeed, it is only recently that the establishment of environmental protection and restoration funds enabled many European countries and the United States to embark on extensive wetland and landscape restoration programs.

\section{References}

Aeschylus. (1975, ca. 430 BC). Prometheus bound, trans. James Scully and C. J. Herington. Oxford, U.K.: Oxford University Press.

Agriantoni, C. 1986. The beginning of industrialisation process in Greece during the 19th century. Athens: Commercial Bank of Greece.

Allen, F. L. 1952. The big change: America transforms itself, 19001950. New York: Harper.

Atkinson, D., and D. Cosgrove. 1998. Urban rhetoric and embodied identities: City, nation, and empire in the Vittorio Emanuele II monument in Rome, 1870-1945. Annals of the Association of American Geographers 88: 28-49.

Banks, I. 1984. The wasp factory. London: Macmillan.
Bauman, Z. 1991. Modernity and ambivalence. Cambridge, U.K.: Polity Press.

Beriatos, E., and J. Colman, eds. 2003. The pulsar effect in urban planning. The 38th International ISoCaRP (International Society of City and Regional Planners) Congress, Athens, September 2002. Volos, Greece: University of Thessaly Press.

Berman, M. 1983. All that is solid melts into air: The experience of modernity. London: Verso.

Bewell, A. J. 1989. Wordsworth and the enlightenment: Nature, man, and society in the experimental poetry. New Haven, CT: Yale University Press.

Brismar, A. 2002. The Atatürk dam project in south-east Turkey: Changes in objectives and planning over time. Natural Resources Forum 26 (2): 101-12.

Buck-Morss, S. 1995. The dialectics of seeing: Walter Benjamin and the Arcades Project. Cambridge, MA: MIT Press.

Burgel, G. 1981. Croissance urbaine et developpement capitaliste: Le "miracle" athenien (Urban growth and capitalist development: The Athenian miracle). Paris: Editions du Centre national de la Recherche scientifique.

Caprotti, F., and M. Kaika. 2002. Fascist nature and the fascist city: Materiality vs. cinematic representation in Mussolini's New Towns. Paper read at the AAG Conference, Los Angeles, 2002.

Castree, N., and B. Braun. 1998. The construction of nature and the nature of construction: Analytical and political tools for building survivable futures. In Remaking reality: Nature at the millennium, ed. B. Braun and N. Castree, 3-42. London: Routledge.

Chant, C. 1989. Science, Technology and everyday life 1870-1950. London: Routledge (in association with The Open University).

Chilvers, I. 1996. Neoclassicism. In The concise Oxford dictionary of art and artists. Oxford Reference Online. Oxford: Oxford University Press. http://www.oxfordreference.com/views/ENTRY.html?subview $=$ Main\&entry=t3.e1726 (last accessed 22 September 2005).

Cholevas, N. T. 1998. The architecture of "transition" in Athens during the interwar period. Athens: Libro.

Clarke, M. 2001. Greek revival. In The concise Oxford dictionary of art terms. Oxford: Oxford University Press. http:// www.oxfordreference.com/views/ENTRY.html?subview= Main\&entry $=\mathrm{t} 4 . \mathrm{e} 824$ (last accessed 22 September 2005).

Clogg, R. 1984. A short history of modern Greece. Cambridge, U.K.: Cambridge University Press.

Constantinou, T., and N. D. Diamantides. 1985. Modeling international migration: Determinants of emigration from Greece to the United States 1820-1980. Annals of the Association of American Geographers 75:352-69.

Cosgrove, D. 1990. An elemental division. In Water, engineering and landscape: Water control and landscape transformation in the modern period, ed. D. Cosgrove and G. Petts, 1-11. London: Belhaven.

Cosgrove, D., and G. Petts, eds. 1990. Water, engineering and landscape: Water control and landscape transformation in the modern period. London: Belhaven.

Cosgrove, D., B. Roscoe, and S. Rycroft. 1996. Landscape and identity at Ladybower Reservoir and Rutland Water. Transactions of the Institute of British Geographers 21 (3): 534-51.

Cronon, W. 1991. Nature's metropolis: Chicago and the Great West. New York: Norton. 
Crouch, D. P. 1993. Water management in ancient Greek cities. New York: Oxford University Press.

Cummings, B. 1990. Dam the rivers, damn the people-Development and resistance in the Amazonian jungle. London: Earthscan.

Daniels, S. 1993. Fields of vision: Landscape imagery and national identity in England and the United States. London: Polity Press.

Demeritt, D. 2001. Being constructive about nature. In Social nature: Theory, practice and politics, ed. B. Braun and N. Castree, 22-40. Oxford: Blackwell.

Desfor, G., and R. Keil. 2004. Nature and the city: Making environmental policy in Toronto and Los Angeles. Tucson: University of Arizona Press.

Doering, M. 2003. The politics of nature: Constructing German reunification during the Great Oder Flood of 1997. Environment and History 9 (2): 195-214.

Dunar, A., and D. McBride. 2001. Building Hoover Dam: An oral history of the Great Depression. Reno: University of Nevada Press.

Eleytheria. 1961. EEY: The progress in the water supply sector. 23 July: 9.

Empros. 1921. The dams. 2 June: 1.

. 1925a. The Municipal gala. 26 April: 4.

- 1925b. The Prime Minister's clarifications. 20 March. . 1925c. The question of real estate taxation. 15 September: 4.

- 1926a. The bonds of the loan for the water supply. 5 October: 3 .

- 1926b. Days of thirst. 9 August: 1 .

. 1926c. Inauguration of the artificial lake of Marathon. 31 August: 2.

. 1926d. Inauguration of the construction works. 31 August: 5.

. 1928. The American business culture in Greece. 4 June: 6.

-1929. Ulen and Co Workers' Committee. 21 December: 3 .

-1930a. Protests against Ulen. 25 August: 4.

- 1930b. Water meters: Popular uprising. 15 August: 4.

Ethnos. 1956. The evolution of Athens's water supply. 6 April: 13.

Etlin, R. A. 1994. Symbolic space: French enlightenment architecture and its legacy. Chicago: University of Chicago Press.

Fischer, F., and M. Hajer. 1999. Living with nature. Oxford, U.K.: Oxford University Press.

Foster, J. B. 2000. Marx's ecology: Materialism and nature. New York: Monthly Review Press.

Frenkel, S. 1996. Jungle stories: North American representations of Tropical Panama. The Geographical Review 86 (3): 317-33.

Gandy, M. 1999. The Paris sewers and the rationalization of urban space. Transactions of the Institute of British Geographers 24 (1): 23-44.

. 2002. Concrete and clay: Reworking nature in New York City. Cambridge, MA: MIT Press.

. 2004. Rethinking urban metabolism: Water, space and the modern city. City: Analysis of Urban Trends, Culture, Theory, Policy, Action 8 (3): 371-87.

Genidounias, T., A. Koumousis, and P. Loprestis. 1923. The water problem of Athens. Athens: Ministry of Transport.

Gerontas, D., and D. Skouzes. 1963. The chronicle of watering Athens. Athens.
Giannakourou, G. 2000. The institutional framework of urban development in Greece: Historical transformations and contemporary demands. In The development of Greek cities: Interdisciplinary approaches for urban analysis and politics, ed. D. Oikonomou and G. Petrakos, 457-80. Volos, Greece: University of Thessaly.

Glacken, C. J. 1967. Traces on the Rhodian shore: Nature and culture in Western thought from ancient times to the end of the eighteenth century. Berkeley: University of California Press.

Godlewska, A. 1995. Map, text and image: The mentality of enlightened conquerors-A new look at the "Description de l' Egypte." Transactions of the Institute of British Geographers 20 (1): 5-28.

Graham, S., and S. Marvin. 2001. Splintering urbanism. London: Routledge.

Green, N. 1990. The spectacle of nature: Landscape and bourgeois culture in nineteenth century France. Manchester, U.K.: Manchester University Press.

Gregory, D. 1994. Geographical imaginations. Oxford, U.K.: Blackwell.

- 1995. Between the book and the lamp: Imaginative geographies of Egypt. Transactions of the Institute of British Geographers 20 (1): 29-56.

Guillerme, A. 1994. Water for the city. Rassegna: Themes in architecture 57:6-21.

Hadjimichalis, C. 1994. The fringes of Europe and EU integration: A view from the south. European Urban and Regional Studies 1 (1): 19-29.

Halliday, S. 1999. The great stink of London: Sir Joseph Bazalgette and the cleansing of the Victorian Metropolis. Stroud: Sutton.

Harvey, D. 1985. The urbanization of capital. Oxford, U.K.: Blackwell.

. 1996. Justice, nature and the geography of difference. Oxford, U.K.: Blackwell.

. 2003. Paris: Capital of modernity. New York: Routledge.

Headrick, D. R. 1981. The tools of empire: Technology and European imperialism in the nineteenth century. New York: Oxford University Press.

-1988. The tentacles of progress: Technology transfer in the age of imperialism, 1850-1940. New York: Oxford University Press.

- 2000. When information came of age: Technologies of knowledge in the age of reason and revolution, 1700-1850. New York: Oxford University Press.

Hebbert, M. 1998. London: More by fortune than design. Chichester, U.K.: Wiley.

Heming, L., P. Waley, and P. Rees. 2001. Reservoir resettlement in China: Past experience and the Three Gorges Dam. Geographical Journal 167 (3): 195-212.

Herf, J. 1984. Reactionary modernism: Technology, culture and politics in Weimar and the Third Reich. Cambridge, U.K.: Cambridge University Press.

Hersey, G. 1988. The lost meaning of classical architecture: Speculations on ornament from Virtruvius to Venturi. Cambridge, MA: MIT Press.

Kafkalas, G. 1981. Regional organisation of the Greek economy, 1948-1974. City and Region: Journal of Spatial Studies 2:738.

Kaika, M. 2003. Constructing scarcity and sensationalising water politics: 170 days that shook Athens. Antipode 35:91954. 
2004. Interrogating the geographies of the gamiliar: Domesticating nature and constructing the autonomy of the modern home. International Journal of Urban and Regional Research 28 (2): 265-86.

. 2005. City of flows: Water, modernity and the city. New York: Routledge.

Kaika, M., and E. Swyngedouw. 2000. Fetishising the modern city: The phantasmagoria of urban technological networks. International Journal of Urban and Regional Research 24 (1): 120-38.

Kalantzopoulos, T. 1964. The history of water supply of Athens. Athens: Palamari Kathrogianni.

Kallis, G., and H. Coccossis. 2000. Metropolitan areas and sustainable use of water: The case of Athens. Final Project Report for METRON (Metropolitan Areas and Sustainable Use of Water). Athens: Commission of the European Communities: Environment and Climate RTD Programme.

Karydis, D. 1988. Composition and evolution of the Greek cities, 15th-19th century. Athens: National Technical University of Athens.

Katz, C., and A. Kirby. 1991. In the nature of things: The environment and everyday life. Transactions, Institute of British Geographers 16 (3): 259-71.

Kirsch, S., and D. Mitchell. 1998. Earth-moving as the "Measure of Man": Edward Teller, geographical engineering, and the matter of progress. Social Text 54:100-34.

Kitchin, R. 2005. Disrupting and destabilizing Anglo-American and English-language hegemony in geography. Social $\mathbb{6}$ Cultural Geography 6 (1): 1-15.

Koliopoulos, J. S., and T. M. Veremis. 2003. Greece: The modern sequel. London: Hurst.

Kordellas, A. 1979. Athens examined from an hydraulic perspective. Athens.

Koronis, S. 1944. Labour policy between the years 1909-1918. Athens.

Kotidis, A. 1993. Modernism and traditionalism in Greek art: 1920-1940. Thessaloniki: University Studio Press.

Koumparelis, S. G. 1989. The history of the water/sewerage works of the Capital. Athens: The Sewerage Company of Athens and The Water Company of Athens.

Latour, B. 1993. We have never been modern. New York: Harvester Wheatsheaf.

Leontidou, L. 1989. Cities of silence: Working class colonisation of urban space, Athens and Pireaus 1909-1940. Athens: Cultural and Technological Institution of the National Bank of Industrial Development of Greece (ETBA).

. 1990. The Mediterranean city in transition: Social change and urban development. Cambridge, U.K.: Cambridge University Press.

Loukaki, A. 1997. Whose genius loci? Contrasting interpretations of the "sacred rock of the Athenian acropolis. Annals of the Association of American Geographers 87: 306-29.

Mantouvalou, M., and L. Martha. 1982. The economic "wonder" and its pitfalls. Anti 199:25-28.

Marcellus, V. D. 1839. Souvenirs de l' Orient (Souvenirs from the Orient). Vol. II. Paris.

Marcus, J. 1988. Art $\mathcal{E}$ anger: Reading like a woman. Columbus: Ohio State University Press.

Marx, K. 1992. Early writings. London: Penguin; New Left Review.

Matless, D. 1992. A modern stream: Water, landscape. modernism, and geography. Environment and Planning D: Society and Space 10:569-88.
McCully, P. 1996. Silenced rivers: The ecology and politics of large dams. London: Zed Books.

McLuhan, M., and Q. Fiore. 1967. The medium is the massage. New York: Bantam.

Michalopoulous, A. 1932. The Greek Water Company: Seven years of water resources management. Ergasia 27 November: 2 .

Michaud, M., and Poujoulat. 1830. Correspondance d' Orient (Correspondence from the Orient). Paris.

Middleton, R., and D. Watkin. 1987. Neoclassical and 19th century architecture/2: The diffusion and development of classicism and the gothic revival. New York: Rizzoli.

Milios, J. 2000. The Greek social formation: From imperialism to capitalist development. Athens: Kritiki.

Moskoph, K. 1974. Ethnic and social consciousness in Greece 1830-1909: The ideology of the comprador space. Athens: Olkos.

Mpiris, K. 1996. Athens from 19th to the 20th century. Athens: Melissa.

National Bank of Greece. 1926. Budget report. Athens: National Bank of Greece.

Oliver, S. 2000. The Thames Embankment and the disciplining of nature in modernity. The Geographical Journal 166 (3): 227-38.

Paraskevopoulos, G. 1907. The mayors of Athens 1835-1907. Athens.

Peckham, R. S. 2001. National histories, natural states: Nationalism and the politics of place in Greece. London: I. B. Tauris.

Picon, A. 1992. French architects and engineers in the age of enlightenment. Cambridge, MA: Cambridge University Press.

Plaskovitis, S. 1961. The dam. Athens: Kedros.

Proudhon, P. J. 1972. System of economical contradictions. New York: Arno Press.

Psiroukis, N. 1964. The Asia Minor disaster 1918-1923. Athens: Korontzi.

_. 1974. The Greek diaspora phenomenon. Athens: Epikairotita.

Rizospastis. 1924. A dubious contract between the state and a foreign company. 23 December: 4.

Robbins, P., A. Polderman, and T. Birkenholtz. 2001. An ecology of the city. Cities 18 (6): 369-80.

Ronning Topping, A. 2000. Great Wall across the Yangtze. Video Production. Producer, E. Perry. United States: pbs home video/itvs.

Said, E. 1995. Orientalism. Harmondsworth, U.K.: Penguin.

Schorske, C. E. 1981. Fin-de-siècle Vienna: Politics and culture. Cambridge, U.K.: Cambridge University Press.

Script. 1904a. A proposal by a foreign company. 16 January: 4.

. 1904b. The question of water supply. 23 April: 3

Sharma, S. R. 1951. The making of modern India. Bombay: Orient Longmans.

Sloulatos, B., N. Dimakopoulos, and S. Kondis. 1984. History of Greece: Modern and contemporary. Vol. 3. Athens: Publishing House for Tutorial Books.

Smith, N. 1984. Uneven development: Nature, capital and the production of space. Oxford, U.K.: Blackwell.

Swyngedouw, E. 1997. Power, nature, and the city. The conquest of water and the political ecology of urbanization in Guayaquil, Ecuador: 1880-1990. Environment and Planning A 29 (2): 311-32. 
1999. Modernity and hybridity: Nature, regeneracionismo, and the production of the Spanish waterscape, 18901930. Annals of the Association of American Geographers 89:443-65.

. 2004. Social power and the urbanisation of water: Flows of power. Oxford, U.K.: Oxford University Press.

. 2005. Geographical revolutions-Scalar politics and the creation of a fascist socio-nature: Franco's wet dream for Spain. Paper presented at the Conference of the Canadian Association of Political Economy, The Political Economy of Scale. York University: Toronto, 3-5 February.

Swyngedouw, E., and M. Kaika. 2000. The environment of the city or. The urbanisation of nature. In A companion to the city, ed. G. Bridge and S. Watson, 567-80. Oxford, U.K.: Blackwell.

Toulmin, S. 1990. Cosmopolis: The hidden agenda of modernity. New York: The Free Press.

Tsaggari, E. 1985. Architectural trends in western Europe and in Greece (1900-1920). In Athens into the 20th century 19001940: Athens the capital of Greece, ed. A. Dimopoulos, 6170. Athens: Greek Ministry of Culture.

Tsotsoros, S. N. 1995. Energy and development during the post-war period: The National Electricity Company, 1950-1992. Athens: Centre for Modern Greek Studies, National Research Institute.

Tsoukalas, K. 1977. Dependency and reproduction: The social role of the educational mechanisms in Greece, 1830-1922. Athens: Themelio.

- 1981. The Greek tragedy. Athens: Nea SynoraLivani.

Tziovas, D. 1989. The transformations of nationalism and the ideology of "Greekness" during the interwar period. Athens: Odysseas.
Ulen \& Co. 1930. The new water supply for Athens, Piraeus $\mathbb{E}$ environs. Athens: Pallis.

Vaiou, D., M. Mantouvalou, and M. Mavridou. 1995. Social inclusion and urban development in a united Europe. Social Sciences Forum 16:29-57.

- 2000. Postwar Greek planning between theory and chance. Conference paper, "Planning in Greece 1949-1974." 2nd conference of the Greek Society for Urban History and Planning, Volos, Greece.

Vaxevanoglou, A. 1996. The social reception of novelty: The example of electrification in Greece during the interwar period. Athens: Centre for Modern Greek Studies, National Research Foundation of Greece.

Vergopoulos, K. 1975. The agricultural question in Greece. Athens: Hexantas.

Water Supply and Sewerage Corporation of Athens (EY $\triangle \mathrm{A \Pi})$. 1925. Completion of the Marathon Works. Agreement signed between the Greek State and Ulen 8 Co. Athens: Water Supply and Sewerage Corporation of Athens.

- 1995. Photographic review. Athens: Water Supply and Sewerage Corporation of Athens.

Watts, J. 2003. After the flood. The Guardian 30 October.

Williams, R. 1990. Notes on the underground. Cambridge, MA: MIT Press.

Wolch, J., S. Pincetl, and L. Pulido. 2002. Urban nature and the nature of urbanism. In From Chicago to L.A.: Making sense of urban theory, ed. M. J. Deer, 367-402. Thousand Oaks, CA: Sage.

Wordsworth, C. 1837. Athens and Attica: Journal of a residence there. London: J. Murray.

Worster, D. 1985. Rivers of empire. New York: Random House.

Zolotas, X. 1964. Greece in the stage of industrialization. Athens: Bank of Greece.

Correspondence: School of Geography, Oxford University, South Parks Road, Oxford, OX1 3QY, United Kingdom, e-mail: maria.kaika@geog.ox.ac.uk. 